\title{
0 Congresso Brasileiro e a Distribuição de Benefícios Sociais no Período 1988-1994: Uma Análise Distributivista*
}

\author{
Leany Barreiro de S. Lemos
}

\section{INTRODUÇ̃̃o}

$\mathrm{O}$ objetivo deste trabalho é apontar as características das escolhas dos parlamentares brasileiros nas áreas de educação e saúde, no período compreendido entre 1988 e 1994, procurando verificar se as propostas legislativas apresentadas pretenderam distribuir benefícios agregados (a grupos, indivíduos ou localidades geográficas) ou difusos (para toda a sociedade). Em outras palavras, quais as opções escolhidas pelos parlamentares, bem como se suas preferências estavam associadas à afiliação partidária ou à região de onde provinham. Lembro aqui que o trabalho se restringe às proposições legislativas (projetos de lei e de decreto legislativo, resoluções etc.), ficando excluídas da análise as emendas orçamentárias apresentadas pelos parlamentares.

As análises foram operacionalizadas a partir das hipóteses formuladas por Santos (1995a), em trabalho que trata das propostas aprova-

\footnotetext{
*Trabalho apresentado na 54를 Conferência Anual da Associação de Ciência Política de Nova Iorque, 14-15 de abril de 2000. Agradeço aos professores Paulo Calmon (UnB), Gláucio Ary Dillon Soares (University of Florida/IUPERJ) e aos pareceristas anônimos de Dados pelos proveitosos comentários. A versão final é de minha total responsabilidade.

DADOS - Revista de Ciências Sociais, Rio de Janeiro, Vol. 44, nº 3, 2001, pp. 561 a 605.
} 
das pelo Congresso no período de 1959 a 1963. Diferentemente de Santos, aqui foram analisadas todas as propostas apresentadas e não só as que se transformaram em norma jurídica. Os pressupostos utilizados foram os da teoria da escolha racional, na sua vertente distributivista.

A hipótese central do trabalho é que a prática legislativa tende a concentrar benefícios em indivíduos ou grupos organizados e nas localidades geográficas que correspondem aos distritos eleitorais dos parlamentares. Ela fundamenta-se no postulado teórico de que os legisladores, sendo racionais, buscarão se reeleger, e que a reeleição é mais fácil de ser atingida quando o parlamentar concentra benefícios em eleitorados específicos. A primeira hipótese subsidiária verifica se a apresentação de propostas concentradoras independe da afiliação partidária; e a segunda se a apresentação de propostas concentradoras independe da região de onde provêm os parlamentares.

Do ponto de vista operacional, foi elaborado um banco de dados, “Legis", com as 817 propostas legislativas nas áreas de educação e saúde apresentadas entre 1988 e 1994, inclusive, gerando mais de 9.800 informações. Assim, além das análises dos componentes distributivo, partidário, regional e temporal das propostas apresentadas, foi possível verificar os grupos que seriam por elas beneficiados; comparar as propostas apresentadas com as efetivamente aprovadas e remetidas à sanção presidencial e os vetos.

Se confirmadas, tais hipóteses rejeitariam a retórica, tão em voga no pós-88, da redução das desigualdades, demonstrando que a prática legislativa concentra benefícios em grupos de interesse ou geográficos, reproduzindo ou mesmo ampliando as assimetrias sociais. Note-se que o intervalo coberto pela pesquisa é um período de consolidação democrática e reformas políticas e econômicas, e que, nesse quadro de consolidação, reforçavam-se as expectativas de que as instituições democráticas - principalmente o Legislativo, por constituir-se a partir da participação direta dos cidadãos — seriam capazes de resolver os problemas sociais que o país enfrentava. É inegável que essa é uma fase em que o Legislativo sofre grandes demandas e que há, em contrapartida, uma ansiedade por parte dos legisladores de, via propostas, reduzir as mazelas sociais - ou de, pelo menos, construir um estereótipo correspondente.

\section{2}


Essas questões são tanto mais problemáticas quando, além do desafio da consolidação democrática, identifica-se a crise socioeconômica que atingiu todos os países na década de 80 e que teve, especialmente no Brasil, a capacidade de acentuar as desigualdades históricas existentes, especialmente no que diz respeito à distribuição de renda e riqueza ${ }^{1}$. A democracia, que era vista como instrumento de superação do atraso, não consegue, somente com suas garantias políticas, reverter o quadro de destituição herdado do regime burocrático-militar. Apesar disso, tida como bem absoluto, ela é consensualmente posta como a única alternativa política viável. O dilema no Brasil é que a crise econômica coincide com o momento da consolidação democrática, e que a ausência de políticas capazes de eliminar a pobreza e de garantir mínimos de cidadania representava um grave risco para a legitimidade do próprio regime em construção.

É no âmbito desse contexto democrático (e, portanto, que concentra novas formas de organização e novos atores) e de crise econômica (que torna a estabilidade econômica prioridade absoluta na agenda governamental ${ }^{2}$ ) que a sociedade se vê debatendo com problemas sociais agudos. $\mathrm{O}$ fato de concentrar-me no Congresso explica-se pelo pressuposto assumido de esse ter um papel importante como formulador de políticas e por ser construído com base na representação democrática (voto) ${ }^{3}$, bem como por sua capacidade de veto na produção de diversas políticas públicas. Além disso, a presente discussão não se circunscreve ao sistema eleitoral ou partidário; ela procura ver o Congresso por dentro.

De forma que a pesquisa sobre o padrão (concentrador ou difusor de benefícios) das proposições que tramitam no Congresso Nacional está articulada com a questão do tipo de política pública adequada para se reverter a situação de pobreza e desigualdade social que macula o país. De um ponto de vista mais amplo, essas questões se inserem no problema de fundo, que é o da construção de um Estado de Bem-Estar brasileiro.

A próxima seção traz um diálogo com a literatura sobre escolha racional e ação legislativa; a terceira seção descreve a metodologia utilizada; a quarta, a análise dos dados, e a última, as considerações finais. 


\section{DIÁLOGO COM A TEORIA: ESCOLHA RACIONAL E AÇÃO LEGISLATIVA ${ }^{4}$}

A despeito de sua complexidade e diferenciações, o modelo de comportamento racional funda-se basicamente nos seguintes elementos:

a) o ator sabe, dentro de certos limites, o que deseja, ou sua preferência;

b) ele é capaz de ordenar suas preferências, metas, valores e estratégias de maneira decrescente (da mais preferida para a menos preferida) e de maneira transitiva (se prefere $A$ a $B$ e $B$ a $C$, preferirá $A$ a $C$ );

c) suas escolhas são consistentes. Uma preferência é consistente se o indivíduo, quando apresentado várias vezes a opções semelhantes, em situações semelhantes, faz sempre as mesmas escolhas;

d) o ator escolherá aquilo que maximizará sua satisfação, dentro de um leque de alternativas finito e fixo, na expectativa de que os benefícios esperados excedam os custos e

e) as ações dos indivíduos serão afetadas pela natureza do bem (se é público ou privado); pelo timing em que os benefícios serão recebidos e em que incorrerão os custos; pela incerteza que pode existir sobre a dimensão exata de custos e benefícios (McKenzie e Tullock, 1985; Green e Shapiro, 1994; Elster, 1989; Przeworski, 1988; Riker, 1990; Knight, 1992).

No modelo apresentado, os legisladores, agindo de acordo com a racionalidade estrita ou instrumental - uso de meios específicos para atingir sua meta - , buscam a maximização de status, poder, dinheiro ou ideologia via reeleição ${ }^{5}$.

Sob a perspectiva neo-institucionalista, os teóricos buscam explicar resultados da ação legislativa tanto a partir das preferências isoladas dos parlamentares quanto das instituições. Surgido na década de 80 , e apontando as instituições como solução teórica para o problema do $\operatorname{caos}^{6}$ e para o teorema da impossibilidade de Arrow ${ }^{7}$, é bem verdade que o neo-institucionalismo se desdobrou em diversas correntes explicativas, deixando de ser um movimento único (Limongi, 1994; Khrebiel, 1991) ${ }^{8}$. Mas sua incorporação do contexto institucional nas análises responde, em certa medida, aos críticos da teoria da escolha racional que apontavam sua incapacidade para incorporar as instituições. Como afirma Riker (1990), qualquer teoria baseada na relação

\section{4}


entre ação racional e instituições sociais deve incorporá-las como reflexo da experiência histórica acumulada ou das experiências socialmente partilhadas.

Sob essa perspectiva, as preferências dos atores políticos deixam de ser a variável independente exclusiva para associarem-se a regras e procedimentos institucionais. As decisões dependem das instituições, dotadas de um papel autônomo, próprio, que induz ao equilíbrio e influencia o resultado substantivo. Como esclarece a equação de Plott, os produtos sociais são a conseqüência da associação de preferências e instituições (Hinich e Munger, 1997). Para os neo-institucionalistas, os aspectos estruturais têm um papel fundamental na produção de resultados políticos e na própria viabilidade do sistema. É na associação de preferências e instituições que se pode compreender os resultados obtidos pelo processo (Khrebiel, 1991; Hinich e Munger, 1997; Limongi, 1994; Santos, 1995a; 1995b).

Os modelos teóricos construídos a partir da abordagem neo-institucionalista podem ser, simplificadamente, classificados como distributivistas, informacionais ou partidários (Limongi, 1994; Khrebiel, 1991). No primeiro caso, o termo distributivo pode ser usado em duas versões diferentes, mas não incompatíveis: pork barrel - concentra benefícios geograficamente e dispersa custos para muitos - e o mais amplo, descrevendo políticas que determinam quem ganha o quê, e quem paga. Em vez de concentrar-se em custos/benefícios, os dois aspectos centrais dessa concepção são escassez e conflito (Khrebiel, 1991).

O modelo informacional enfatiza a estrutura institucional - em especial, como as Comissões desempenham papel preponderante na coleta das informações necessárias ao andamento legislativo e na distribuição dessas informações entre os congressistas. A tradição informacional é menos extensa do que a distributivista e tem como maior expoente Keith Khrebiel. Sua formulação está atada a dois postulados fundamentais: o do primado da decisão majoritária e o da incerteza quanto aos resultados das políticas, que leva os parlamentares a agirem de forma a evitar riscos (Limongi, 1994; Khrebiel, 1991). Expertise é fundamental para tornar o processo eficiente (aproximando as políticas aos resultados desejados) e assim possibilitar o alcance do objetivo final — a reeleição. 
É curioso notar que as perspectivas distributivista e informacional são parecidas em dois aspectos: ambas encaram a política como jogo de conflito, e os conflitos são resolvidos por atores racionais, orientados para uma meta. Mas apresentam diferenças, pois o majoritarianismo - todas as decisões internas têm por base a vontade da maioria - é mais abrangente na perspectiva informacional - e a incerteza, que está ausente na distributivista, é crucial na outra abordagem. Mais uma diferenciação é que, enquanto no modelo distributivista o equilíbrio legislativo é estável, no informacional ele é definido em termos do comportamento e das crenças dos jogadores, e não em termos da estabilidade dos resultados (Khrebiel, 1991).

No modelo partidário, os resultados dependem essencialmente do partido majoritário que estiver no poder, e o processo legislativo é visto como tendencialmente favorável a ele. Essa abordagem rejeita a dicotomia distributivismo/informacionismo e entende o trabalho das Comissões como "cartéis legislativos" ou governo partidário, e o processo legislativo é visto como totalmente favorável aos partidos majoritários. As "regras cartelizadas", ao lado da atuação de lideranças privilegiadas dos partidos maiores, favoreceriam os membros de tais partidos, que teriam seus acordos e projetos mais facilmente aprovados (Limongi, 1994).

Essa é a mais heterodoxa das versões ao apontar que as Comissões são instrumentalizadas pelos partidos políticos. Por sua vez, os partidos têm como principal fonte de poder a capacidade de controlar a agenda decisória. Além disso, o presidente da Casa, o líder do partido majoritário e a Comissão de Resolução detêm grande poder na estrutura legislativa e, sendo esses cargos indicados pelos partidos, estes acabam dominando a instituição por meio de cargos na administração e ocupando posição de relevo nas Comissões (idem). Após a década de 70 , os autores afiliados à versão partidária passam a reconhecer que o novo Congresso apresenta pontos de tensão entre partidos e indivíduos.

Apesar de os três modelos portarem vantagens e possibilidades de interpretação dos mais variados aspectos da estrutura legislativa, utilizou-se aqui o modelo distributivo. Essa escolha foi realizada especialmente pela afirmação corrente em uma parte da literatura e no senso comum sobre a paroquialidade dos políticos brasileiros, que estariam voltados única e exclusivamente para a maximização dos inte-

\section{6}


resses individuais. Essa característica, aliada a um certo diagnóstico de ausência de partidos e instâncias de controle do comportamento parlamentar, também afirmada na literatura e no discurso cotidiano, redundaria em ambiente propício ao distributivismo.

Basicamente, o modelo distributivista pressupõe que o ponto de partida analítico deve ser a motivação do parlamentar. Como convém à interpretação racionalista, sua motivação e preferência é a da maximização eleitoral - reeleição. O Legislativo é um corpo que se caracteriza por escolhas coletivas e que tem como tarefa principal alocar benefícios em forma de políticas. Uma vez que os legisladores estão sujeitos a eleições periódicas, e o espaço eleitoral é o geográfico, a "conexão eleitoral" significa que todo membro do Congresso tem fortes incentivos para atender aos interesses específicos dos eleitores de sua região.

No vernáculo dos modelos econômicos, o aspecto fundamental dos legislativos, na democracia, é a oportunidade que existe para legisladores racionais, maximizadores de utilidade, capturar ganhos de mercado (Khrebiel, 1991). Os distributivistas ponderam, então, que o desafio da organização legislativa é essa captura de ganhos de mercado de forma previsível e confiável. Ainda que isso seja complicado em uma instituição que baseia suas votações na regra da maioria onde a estabilidade é mais difícil de ser alcançada do que o seria por meios contratuais ou de mercado (Weingast e Marshall, 1988) -, existem fortes instrumentos que coagem os participantes a agir cooperativamente.

Regras e princípios são os instrumentos facilitadores dos ganhos, ao distribuírem aos parlamentares direitos de acordo com a intensidade de suas preferências. Cada congressista oferece concessões em políticas que são percebidas pelo seu eleitorado como menos importantes, enquanto colhe benefícios desproporcionais em temas de especial importância para seus eleitores. Há, portanto, uma assimetria intencional na distribuição de direitos, que, por sua vez, gera vieses intencionais na provisão de benefícios políticos (Khrebiel, 1991).

Por outro lado, isso implica que os parlamentares não ajam de forma sempre responsiva ou sob o domínio absoluto da vontade do eleitorado; nas vezes em que a reeleição não se encontra sob risco, podem agir com maior liberdade (Arnold, 1991) ${ }^{9}$. No que diz respeito às Comis- 
sões, elas estariam organizadas de forma a anular a instabilidade da maioria, enquanto concedem benefícios desproporcionais aos seus membros. Assim, o poder comissional refere-se a comportamento que resulta em ganhos para a Comissão, a expensas da maioria.

Em poucas palavras, a política distributivista é definida, por vários autores, como a distribuição de benefícios particularistas com uma correspondente distribuição de custos generalizados. Como a situação é de escolha coletiva com escassez de recursos, o conflito é inevitável, embora haja a possibilidade de ganhos. Os princípios gerais dessa abordagem podem ser assim resumidos:

a) os congressistas, como agentes racionais, buscam a reeleição;

b) para isso, eles precisam apresentar propostas que seus eleitores percebam como benéficas, com um custo proporcionalmente inferior ao benefício;

c) ao buscar benefícios para seus distritos, em face da escassez de recursos, instauram o conflito;

d) a organização interna do Congresso propicia aos parlamentares a possibilidade de apresentar propostas que lhes dêem retorno eleitoral graças a dois mecanismos institucionais: o logrolling (troca de votos, resultado inexorável do princípio da maioria, formando um mercado de votos no interior do Congresso) e a divisão de tarefas, via Comissões (com o monopólio de proposição em sua jurisdição, composição de membros que dependem da provisão de benefícios e poderes especiais que anulam a estabilidade da maioria);

e) o papel da instituição é garantir estabilidade ao processo de troca de votos, ao fim do qual o parlamentar pode reeleger-se e

f) o voto geográfico tem importante papel, uma vez que estabelece eleitorado localizado, favorecendo, assim, o atendimento de interesses concentrados (Limongi, 1994; Khrebiel, 1991; Hinich e Munger, 1997; Arnold, 1991; Santos, 1995a; 1995b).

Trabalho relevante utilizando análise distributivista sobre o comportamento parlamentar no Brasil é o de Santos (1995a; 1995b). Embora seu objetivo se circunscreva, no primeiro texto, a explicar a produção legislativa no período 1959-1963, descartando as hipóteses clássicas do Congresso como obstáculo ao desenvolvimento econômico ${ }^{10}$ ou

\section{8}


como "engenho de inflação"11, sua maior virtude é estabelecer uma tipologia do padrão decisório baseada na questão "quem ganha o quê, quem paga" - ou no cálculo custo/benefício - , que é recuperada na parte empírica deste trabalho. Seu argumento segue o de um trabalho teórico anterior, de Douglas Arnold (1991), que procura explicar a lógica da ação congressual.

Também baseado na maximização eleitoral e de cunho distributivista, o trabalho de Arnold reconhece a existência abundante de propostas que concentram benefícios em grupos de interesse e em localidades geográficas específicas (de fácil entendimento, porque são facilmente reconhecíveis pelo eleitorado) e busca motivações para a existência de políticas que concedam benefícios difusos. Sua explicação, para esse caso, é que os legisladores não agem somente respondendo a pressões e a interesses específicos de públicos atentos ${ }^{12}$, mas freqüentemente antecipam políticas que, avaliam, podem tornar-se importantes no futuro - as "preferências potenciais"13 (idem).

Apesar de também trabalhar com a incidência de custos e benefícios, a análise de Arnold é mais profunda e define um segundo atributo das políticas: a natureza da cadeia causal que liga um instrumento de política aos efeitos de política. Além disso, introduz o fato de que a incidência de benefícios não se dá com base somente na localização geográfica do eleitorado, mas também com relação a grupos específicos de interesse, além de reconhecer a existência de interesses comuns, gerais (idem).

A análise dos dados baseou-se na distribuição de benefícios para indivíduos, grupos e localidades geográficas, ou para a sociedade em geral, conforme postulado da vertente distributivista. Procurou-se apreender as características intrínsecas às propostas legislativas apresentadas pelos parlamentares nas áreas de educação e saúde, de 1988 a 1994, verificando, igualmente, se há variação nas escolhas segundo a região de origem ou a afiliação partidária do representante.

\section{POLIITICAS SOCIAIS NO CONGRESSO: HIPÓTESES E METODOLOGIA}

\section{Pressupostos}

1. O Legislativo tem papel fundamental como formulador de politicas, especialmente porque admite o controle do eleitorado. Estudos mais recentes das relações Executivo/Legislativo apontam a preponderância do 
primeiro sobre o último (Figueiredo e Limongi, 1994a; 1994b; 1995; 1999). Ainda que esta última afirmação seja verdadeira, não se pode negar as prerrogativas constitucionais do Poder Legislativo, seu poder de apresentar propostas de políticas e de vetá-las. Além disso, diferentemente da burocracia, que é quem de fato formula as políticas no Executivo, os parlamentares são submetidos a controle periódico via eleições, o que lhes dá um caráter mais público e aberto.

2. Os parlamentares buscam maximizar suas preferências, conforme a racionalidade restrita: a reeleição é a principal meta. Não se especulará se as motivações do parlamentar são altruístas ou egoístas.

3. Os atores agem constrangidos por regras e procedimentos institucionais, que restringem escolhas e ajudam a moldar padrões, mas são incapazes de determinar sozinhos o resultado final.

Dessas assertivas surge a hipótese central do trabalho:

Predominam no Legislativo propostas que distribuem benefícios concentrados e custos difusos, em detrimento de propostas que auferem benefícios difusos. Segundo a literatura, as políticas que auferem benefícios a uma minoria e cujos custos são distribuídos entre a maioria - e são, portanto, minimamente percebidos por essa maioria — são mais fáceis de serem percebidas como "boas políticas" e atendem mais satisfatoriamente ao propósito de reeleição do parlamentar. Por "predominam", entendo a maioria simples $(50 \%+1$ das propostas). Derivam-se duas hipóteses subsidiárias:

1. A apresentação de propostas concentradoras independe da afiliação partidária dos proponentes - a intenção é verificar se existe correlação entre partido político e apresentação de propostas concentradoras de benefícios. Em outras palavras, a prática da apresentação desse tipo de política está vinculada a partidos políticos? Se está, são partidos em um espectro mais à esquerda ou mais à direita?

2. Aapresentação de propostas concentradoras independe da origem regional dos proponentes - da mesma forma que no item anterior, a idéia traduzida nessa proposição é a da universalidade do comportamento parlamentar. Esta hipótese nega a afirmação presente no senso comum e em vários trabalhos acadêmicos de que os representantes de regiões menos desenvolvidas economicamente são paroquiais.

\section{0}


Para testagem das hipóteses, a variável independente foi Transferência Concentrada de Recursos - TCR ou Regulação Concentrada $\mathrm{RC}$, e as dependentes foram partido político e localidade geográfica.

\section{Tipologia}

Para fins de análise, uma proposta legislativa pode ser observada segundo duas dimensões: quanto à forma e quanto ao escopo. A forma diz respeito à maneira pela qual uma decisão legislativa concede benefícios, e pode apresentar-se como regulação (da economia ou das próprias regras procedimentais) ou como transferência de renda, patrimônio ou recursos da União para o benefício de grupos, regiões e empresas.

Em relação ao escopo, as leis podem ser concentradas ou difusas. No primeiro caso, concederão privilégios financeiros, patrimoniais ou de status exclusivamente a um indivíduo, grupo, empresa ou localidade geográfica. No segundo caso, as leis não farão referência direta a indivíduos, empresas, grupos ou localidades - ou, quando o fizerem, terão em vista atenuar condições adversas econômicas ou naturais - , concedendo assim benefícios difusos.

Estão, assim, disponíveis para análise quatro tipos de decisões:

1. Transferência de recursos da União para indivíduos, empresas, grupos econômicos ou localidades - Transferência Concentrada de Recursos - TCR;

2. Regulação das atividades de grupos especiais - Regulação Concentrada - RC;

3. Transferência de recursos para proteção e segurança da população em geral - Transferência Difusa de Recursos - TDR;

4. Regras gerais que regulam o conflito distributivo e a competição e participação políticas - Regulação Difusa - RD ${ }^{14}$.

Quadro 1

Tipos de Decisões Tomadas por Parlamentares

\begin{tabular}{|l|c|c|}
\hline & Transferência de Recursos & Regulação \\
\hline Benefícios concentrados & 1 & 2 \\
Benefícios difusos & 3 & 4 \\
\hline
\end{tabular}

Fonte: Santos (1995a:462). 
Para realizar este trabalho fiz, primeiramente, um levantamento de todas as propostas legislativas nas áreas de educação e saúde, apresentadas pelos parlamentares entre outubro de 1988 e dezembro de 1994. Alguns outros aspectos das proposições foram indexados, além de seu caráter concentrador-difusor: a) a classificação formal da proposta - i.e., se ela se originou na Câmara dos Deputados, Senado, Comissões; se é um projeto de legislação ordinária, complementar, de resolução, de emenda constitucional, uma mensagem do Congresso ou um projeto de decreto legislativo deste; b) seu número protocolar; c) data de apresentação da proposta; d) última tramitação e data respectiva; e) partido político do proponente; f) Estado da federação do proponente; g) região do proponente; h) classe - o cerne do banco de dados - aqui, as proposições legislativas foram classificadas de acordo com o Quadro 1; i) grupo ou indivíduo que se beneficiaria com a regulação concentrada ou com a transferência concentrada de recursos; j) estilo - se é uma proposição simples ou se incorpora outros elementos (tipo "ônibus"); k) área da proposição — se é de educação, saúde ou mista (incorpora elementos das duas áreas - i.e., uma mudança curricular que inclua higiene bucal como disciplina obrigatória nas escolas de $1^{\circ}$ grau).

Como os números absolutos, e mesmo as porcentagens, poderiam maquiar os resultados por causa da diferença numérica de bancadas partidárias e de bancadas regionais, foi criado o Índice de Atividade Legislativa - IAL, que traduz o número de propostas legislativas apresentadas por cada parlamentar de cada região ou partido. O IAL foi calculado da seguinte forma:

1. para região: $\mathrm{IAL}=\frac{\mathrm{n}^{\circ} \text { de propostas classificadas }}{\mathrm{n}^{\circ} \text { de parlamentares de cada uma das regiões }}$

2. para partido político: $\mathrm{IAL}=\frac{\mathrm{n}^{\circ} \text { de propostas classificadas }}{\mathrm{n}^{\circ} \text { de parlamentares de cada }}$

partido político

Não houve problemas quanto ao IAL regional, posto que o número de parlamentares por estado e, conseqüentemente, por região, é constante (Tabela 1). 
O Congresso Brasileiro e a Distribuição de Benefícios Sociais...

Tabela 1

Representação de Deputados e Senadores, por Região

1988-1994

\begin{tabular}{l|c|c|c|c|c|c}
\hline & Centro-Oeste & Norte & Nordeste & Sul & Sudeste & Total \\
\hline Câmara & 41 & 65 & 151 & 77 & 169 & 503 \\
Senado & 15 & 18 & 27 & 9 & 12 & 81 \\
\hline Total & $\mathbf{5 6}$ & $\mathbf{8 3}$ & $\mathbf{1 7 8}$ & $\mathbf{8 6}$ & $\mathbf{1 8 1}$ & $\mathbf{5 8 4}$ \\
\hline
\end{tabular}

Fontes: Secretaria-Geral da Mesa da Câmara dos Deputados e Secretaria-Geral da Mesa do Senado Federal.

Para o cálculo do IAL partidário foi preciso estabelecer uma média de parlamentares por partido, em face da grande mobilidade interpartidária. A média foi calculada com base nos números das bancadas no início da $49^{a}$ legislatura (1991) e no das bancadas ao fim da mesma legislatura (1995), conforme a Tabela 2.

Tabela 2

Média de Representação de Deputados e Senadores, por Partido 1991-1995

\begin{tabular}{l|ccc|ccc|c}
\hline & $\begin{array}{c}\text { Câmara dos } \\
\text { Deputados }\end{array}$ & Média & Senado & Média & $\begin{array}{c}\text { Média } \\
\text { Geral }\end{array}$ \\
\hline & $1 / 2 / 91$ & $25 / 1 / 95$ & $1991-1995$ & $1 / 2 / 91$ & $25 / 1 / 95$ & $\begin{array}{c}1991- \\
1995\end{array}$ & $\begin{array}{c}1991- \\
1995\end{array}$ \\
\hline PMDB & 108 & 93 & 100,5 & 27 & 27 & 27 & 127,5 \\
PFL & 83 & 87 & 85 & 17 & 14 & 15,5 & 100,5 \\
PDT & 46 & 35 & 40,5 & 5 & 4 & 4,5 & 45 \\
PSDB & 38 & 46 & 42 & 9 & 10 & 9,5 & 51,5 \\
PTB & 37 & 30 & 33,5 & 8 & 4 & 6 & 39,5 \\
PDS (PPR-PDC) & 65 & 68 & 66,5 & 8 & 10 & 9 & 75,5 \\
PT & 35 & 35 & 35 & 1 & 1 & 1 & 36 \\
Peq. Dir. ${ }^{* *}$ & 72 & 86 & 79 & 5 & 10 & 7,5 & 86,5 \\
Peq. Esq. ${ }^{* * *}$ & 19 & 23 & 21 & 1 & 1 & 1 & 22 \\
\hline Total & $\mathbf{5 0 3}$ & $\mathbf{5 0 3}$ & $\mathbf{5 0 3}$ & $\mathbf{8 1}$ & $\mathbf{8 1}$ & $\mathbf{8 1}$ & $\mathbf{5 8 4}$ \\
\hline
\end{tabular}

Fontes: Secretaria-Geral da Mesa da Câmara dos Deputados e Secretaria-Geral da Mesa do Senado Federal.

* O PDS juntou-se ao PDC para conformar o PPR. Em 1995, o PPR juntou-se com o PP e tornou-se o PPB.

** Pequenos partidos (direita): PRN, PL, PSC, PST, PTR, PMN, PSD, PRONA, PJ, PP, PTdoB.

***Pequenos partidos (esquerda): PSB, PCdoB, PCB, PPS, PSTU, PV. 
Além da testagem das três hipóteses, foram ainda considerados três problemas cruciais:

1. variação temporal das propostas - elas foram agregadas conforme o ano, para a verificação da hipótese de que a sua apresentação se concentra em períodos pré-eleitorais (entenda-se como período pré-eleitoral o ano das eleições);

2. variação das propostas concentradoras conforme o grupo de interesse - para verificar quais os grupos que mais conseguem captar ganhos legislativos, em que proporção e por intermédio de que partidos;

3. características das propostas aprovadas em oposição às apresentadas no Congresso.

\section{ANÁLISE DOS DADOS}

\section{Hipótese Central}

Do total de 817 propostas legislativas de educação e saúde apresentadas no período que vai de 1988 a 1994, temos a seguinte situação:

Tabela 3

Propostas Legislativas nas Áreas de Educação e Saúde no Período de 1988 a 1994,

\begin{tabular}{l|c|c|c|c|c|c|c}
\multicolumn{10}{|c}{ segundo Forma e Escopo } \\
\hline & $\begin{array}{c}\text { Transfe- } \\
\text { rência } \\
\text { Concen- } \\
\text { trada de } \\
\text { Recursos }\end{array}$ & $\begin{array}{c}\text { Regula- } \\
\text { ção Con- } \\
\text { centrada }\end{array}$ & Subtotal & $\begin{array}{c}\text { Transfe- } \\
\text { rência } \\
\text { Difusa de } \\
\text { Recursos }\end{array}$ & $\begin{array}{c}\text { Regula- } \\
\text { ção Difu- } \\
\text { sa }\end{array}$ & Subtotal & Total \\
\hline Educação & 61 & 55 & 116 & 41 & 169 & 210 & 326 \\
& $(7,47 \%)$ & $(6,73 \%)$ & $(14,20 \%)$ & $(5,02 \%)$ & $(20,69 \%)$ & $(25,70 \%)$ & $(39,90 \%)$ \\
\hline Mista* & 4 & 20 & 24 & 18 & 36 & 54 & 78 \\
& $(0,49 \%)$ & $(2,45 \%)$ & $(2,94 \%)$ & $(2,20 \%)$ & $(4,41 \%)$ & $(6,61 \%)$ & $(9,55 \%)$ \\
\hline Saúde & 42 & 148 & 190 & 36 & 187 & 223 & 413 \\
& $(5,14 \%)$ & $(18,12 \%)$ & $(23,26 \%)$ & $(4,41 \%)$ & $(22,89 \%)$ & $(27,29 \%)$ & $(50,55 \%)$ \\
\hline Total & $\mathbf{1 0 7}$ & $\mathbf{2 2 3}$ & $\mathbf{3 3 0}$ & $\mathbf{9 5}$ & $\mathbf{3 9 2}$ & $\mathbf{4 8 7}$ & $\mathbf{8 1 7}$ \\
IAL** & $\mathbf{( 1 3 , 1 0 \% )}$ & $\mathbf{( 2 7 , 2 9 \% )}$ & $\mathbf{( 4 0 , 3 9 \% )}$ & $\mathbf{( 1 1 , 6 3 \% )}$ & $\mathbf{( 4 7 , 9 9 \% )}$ & $\mathbf{( 5 9 , 6 1 \% )}$ & $\mathbf{( 1 0 0 , 0 0 \% )}$ \\
\hline
\end{tabular}

Fonte: Legis.

* Incorpora ambas as áreas.

**Índice de Atividade Legislativa.

\section{4}


Os dados refutaram a hipótese principal de que preponderam propostas legislativas concentradoras de benefícios em relação a propostas que difundem benefícios. Houve $59,61 \%$ de propostas deste último tipo, em oposição a 40,39\% de propostas concentradoras de benefícios. O IAL demonstra, igualmente, que a média de propostas concentradoras, por parlamentar, foi de 0,57 , contra 0,83 para propostas difusoras de benefícios. Por que os parlamentares escolheriam apresentar propostas deste último tipo, quando as concentradoras são mais traceable e teoricamente capazes de tornar possível a reeleição? Seriam os representantes irracionais?

Segundo a literatura, as propostas concentradoras têm uma probabilidade maior de serem reconhecidas como desejáveis pelos eleitores, uma vez que correspondem a demandas claras e previsíveis. Entretanto, como aponta Arnold (1991), os benefícios difusos podem maximizar a utilidade: existem as "preferências potenciais", i.e., aquelas que, de alguma forma, podem influenciar a atitude do eleitorado no momento da votação, não precisando estar ligadas a um ganho específico.

A preferência potencial significa que o eleitor desatento é capaz de influenciar a decisão mesmo não havendo uma manifestação explícita de sua vontade. A matéria em análise, mesmo não sendo reivindicação do eleitorado, pode tornar-se importante em época de eleições. Assim, o parlamentar age não só para satisfazer as aspirações imediatas dos eleitores, mas calcula conforme as possibilidades futuras de sua decisão afetar a avaliação sobre sua atuação. Existem ainda cinco outras explicações possíveis para a preponderância de propostas de caráter difuso sobre as de caráter particularista, ou concentrado:

a) a maior parte das propostas não ameaça a reeleição;

b) a preponderância de propostas difusoras está ligada não à racionalidade instrumental, mas a valores compartilhados sobre políticas ideais para a sociedade como um todo;

c) a reeleição depende da percepção do eleitorado sobre o desempenho do parlamentar. Esta percepção não precisa necessariamente estar ligada a um ganho individual. Ganhos coletivos, independentemente de localização geográfica ou pertencimento a um grupo específico, podem ser mais desejáveis do que ganhos individuais. Dizer que os indivíduos buscarão ganhos individuais é tão arbitrário quanto afir- 
mar que buscarão ganhos partilhados. Segundo esse argumento, o modelo racional se mantém, embora em uma base coletivista. Em poucas palavras, a proposta difusa também teria cunho pragmático;

d) a apresentação de propostas tem pouca influência no cálculo do eleitor. Como a falta de interesse do cidadão não ameaça a reeleição, os parlamentares têm uma margem maior de liberdade para atuar na arena propositiva, podendo apresentar propostas de cunho difuso. Essa interpretação é embasada também pelo argumento de Arnold (idem), de que a avaliação retrospectiva do parlamentar - com base em sua atuação passada - é apenas uma das formas de avaliação do eleitorado. Existem também a avaliação retrospectiva do partido com base em posicionamentos partidários - e as avaliações prospectivas - a partir de avaliações sobre promessas de campanha - do candidato e do partido. Atrelada a esse fato, que a avaliação é complexa e multidimensional, está a observação de Khrebiel (1991) de que a decisão do parlamentar ocorre em um contexto de incertezas e de que o parlamentar é avesso ao risco (risk averse);

e) a apresentação de propostas não implica sua aprovação ou implementação. Assim, os parlamentares apresentam propostas difusoras para tomar posição e construir um estereótipo que possa corresponder ao ideal de representante do eleitor, mesmo sabendo que as propostas podem não ser aprovadas ou implementadas.

Outra questão que merece destaque é relacionada à forma das proposições. O número de propostas regulatórias superou o de transferidoras. Tal fato pode estar condicionado a:

a) baixa capacidade de transferência de recursos pelo Legislativo - é do Executivo o poder de propor o orçamento, cabendo ao Legislativo emendá-lo e aprová-lo. Mas a distribuição de recursos é anteriormente determinada pelo Executivo - ainda que muito se tenha a falar sobre as ingerências políticas no processo de elaboração orçamentária. Ao Legislativo falta, de um lado, expertise para elaborar novas políticas sem influenciar a política econômica, de tal forma que os próprios parlamentares e a opinião pública possam considerar desastrosa ${ }^{16}$; de outro, prerrogativa institucional: a Constituição de 1988 estabelece que somente se pode criar despesa se apontando a fonte de recursos financiadora. Os constrangimentos apontados favorecem a apresentação de propostas regulatórias, através das quais os parlamentares

\section{6}


não alocam benefícios, mas marcam posicionamentos e evitam a rejeição do eleitorado. Além disso, o monopólio do presidente da República para iniciar matérias orçamentárias e tributárias impede que o Legislativo possa, nessas arenas distributivas por definição, transferir benefícios;

b) segmentação da atividade legislativa - de fato, os parlamentares trabalham em uma instituição complexa, com regras variadas para arenas diferentes. Um Congresso segmentado teria dois cortes: vertical-hierárquico (Mesa Diretora, Comissões, Plenário) e horizontal. No caso brasileiro, haveria pelo menos cinco arenas horizontais no Legislativo: administrativa; propositiva, onde a regulamentação impera; orçamentária, arena concentradora de benefícios por definição; fiscalização e controle; medidas provisórias e propostas de emenda constitucional, que demandam quóruns específicos e, no caso das medidas provisórias, um locus específico - o Congresso Nacional. A maximização eleitoral pode ser alcançada de maneiras diferentes, com instrumentos variados em cada uma das arenas.

Um padrão de ordenamento das escolhas ${ }^{17}$ dos parlamentares quanto à apresentação de propostas também foi identificado: Regulação Difusa > Regulação Concentrada > Transferência Concentrada de Recursos > Transferência Difusa de Recursos. Este padrão demonstra que, visto como instituição, e no que tange às proposições legislativas, o Congresso Nacional é mais regulador que transferidor de recursos; e que não há uma preponderância do comportamento concentrador entre os parlamentares.

\section{Como funciona a lógica partidária}

A primeira subhipótese testada foi que a apresentação das propostas concentradoras independeria da coloração partidária dos proponentes. Tal hipótese foi confirmada pelos dados coletados. Não há um partido ou bloco responsável por um hipotético perfil distributivista, ou "paroquial", do Legislativo (Tabela 4). Todos os partidos preferem a apresentação de propostas difusas a propostas concentradoras.

A atividade legislativa é mais intensa em determinados partidos. Números absolutos mostram que os partidos da direita - PDS, PFL e PTB - apresentaram um número maior de propostas do que partidos de centro e de esquerda. No entanto, ao aplicar-se o IAL, verifica-se 
Tabela 4

Partidos Políticos e Distribuição de Benefícios:

Propostas Legislativas em Saúde e Educação

1988-1994

\begin{tabular}{|c|c|c|c|c|c|c|c|c|c|c|c|c|}
\hline & & $\begin{array}{l}\text { Peq. } \\
\text { (esq.) }\end{array}$ & PT & PDT & PSDB & PMDB & РТВ & PFL & PDS* & $\begin{array}{l}\text { Peq. } \\
\text { (dir.) }\end{array}$ & $\mathrm{COM}^{* *}$ & Total \\
\hline $\begin{array}{l}\text { Benefícios } \\
\text { concentrados }\end{array}$ & IAL & $\begin{array}{c}11 \\
(1,35 \%) \\
0,50\end{array}$ & $\begin{array}{c}26 \\
(3,18 \%) \\
0,72\end{array}$ & $\begin{array}{c}43 \\
(5,26 \%) \\
0,96\end{array}$ & $\begin{array}{c}35 \\
(4,28 \%) \\
0,68\end{array}$ & $\begin{array}{c}63 \\
(7,71 \%) \\
0,49\end{array}$ & $\begin{array}{c}21 \\
(2,57 \%) \\
0,53\end{array}$ & $\begin{array}{c}46 \\
(5,63 \%) \\
0,46\end{array}$ & $\begin{array}{c}27 \\
(3,30 \%) \\
0,36\end{array}$ & $\begin{array}{c}35 \\
(4,28 \%) \\
0,40\end{array}$ & $\begin{array}{c}23 \\
(2,82 \%) \\
0,00\end{array}$ & $\begin{array}{c}330 \\
(40,39 \%) \\
0,57\end{array}$ \\
\hline $\begin{array}{l}\text { Benefícios } \\
\text { difusos }\end{array}$ & IAL & $\begin{array}{c}12 \\
(1,47 \%) \\
0,55\end{array}$ & $\begin{array}{c}33 \\
(4,04 \%) \\
0,92\end{array}$ & $\begin{array}{c}55 \\
(6,73 \%) \\
1,22\end{array}$ & $\begin{array}{c}76 \\
(9,30 \%) \\
1,48\end{array}$ & $\begin{array}{c}109 \\
(13,34 \%) \\
0,85\end{array}$ & $\begin{array}{c}26 \\
(3,18 \%) \\
0,66\end{array}$ & $\begin{array}{c}76 \\
(9,30 \%) \\
0,76\end{array}$ & $\begin{array}{c}45 \\
(5,51 \%) \\
0,60\end{array}$ & $\begin{array}{c}46 \\
(5,63 \%) \\
0,53\end{array}$ & $\begin{array}{c}9 \\
(1,10 \%) \\
0,00\end{array}$ & $\begin{array}{c}487 \\
(59,61 \%) \\
0,83\end{array}$ \\
\hline Total & IAL & $\begin{array}{c}23 \\
(2,82 \%) \\
1,05\end{array}$ & $\begin{array}{c}59 \\
(7,22 \%) \\
1,64\end{array}$ & $\begin{array}{c}98 \\
(12,00 \%) \\
2,18\end{array}$ & $\begin{array}{c}111 \\
(13,59 \%) \\
2,16\end{array}$ & $\begin{array}{c}172 \\
(21,05 \%) \\
1,35\end{array}$ & $\begin{array}{c}47 \\
(5,75 \%) \\
1,19\end{array}$ & $\begin{array}{c}122 \\
(14,93 \%) \\
1,21\end{array}$ & $\begin{array}{c}72 \\
(8,81 \%) \\
0,95\end{array}$ & $\begin{array}{c}81 \\
(9,91 \%) \\
0,94\end{array}$ & $\begin{array}{c}32 \\
(3,92 \%) \\
0,00\end{array}$ & $\begin{array}{c}817 \\
(100,00 \%) \\
1,40\end{array}$ \\
\hline
\end{tabular}

Fonte: Legis.

* O PDS fundiu-se com o PDC, transformando-se em PPR. Posteriormente, em 1995, o PPR fundiu-se com o PP para gerar o PPB.

${ }^{* *} \mathrm{COM}=$ Comissões 
que os representantes de partidos de centro-esquerda são os que apresentam mais propostas (especificamente, PDT e PSDB) ${ }^{18}$. Além disso, o número de propostas concentradoras apresentadas por partidos à esquerda superou o número de propostas apresentadas por partidos à direita do espectro ideológico. Essa constatação contradiz a idéia de um perfil concentrador e paroquial de partidos conservadores, contra uma imagem coletivista e difusora de partidos de esquerda. Todos preferem propor difusamente; mas todos propõem concentradamente e o que varia é o grupo beneficiado ${ }^{19}$.

Uma explicação possível para a esquerda legislar de maneira mais concentradora pode repousar no fato de que seu eleitorado se compõe de um público atento ou de corpos organizados que acompanham e controlam seus representantes. Aparentemente, os parlamentares apresentam propostas ou como antecipação a demandas eleitorais ou como uma resposta concreta a pressões, para identificarem-se com uma causa social em particular e, assim, construir uma imagem positiva em relação aos eleitores ${ }^{20}$. Por outro lado, partidos de direita, tendo hipoteticamente sua base eleitoral formada por grupos não organizados/eleitores desatentos, teriam uma margem maior de liberdade de atuação.

Pode-se, também, analisar o fato de as esquerdas e o centro apresentarem mais propostas concentradoras que a direita, também como um reflexo do eleitorado de tipo corporativo que aqueles partidos possam ter. Estando ligados a sindicatos de trabalhadores de modo geral, e podendo ter uma parte de suas bancadas eleita por categorias profissionais específicas, alguns parlamentares da esquerda e do centro podem buscar a maximização eleitoral, representando enfaticamente interesses de corporações.

Não se trata aqui de valorar se são boas ou ruins as possíveis intervenções e capitalizações de benefícios por parte de grupos profissionais, dado que serão legítimas, dentro de regras institucionais consolidadas segundo os princípios da democracia representativa. Entretanto, deve-se questionar até que ponto essas intervenções não se tornam um contrapeso em relação a grupos dentro da sociedade que, à margem do mercado de trabalho e da representação sindical, estão excluídos do usufruto dos benefícios angariados. No item que trata dos grupos beneficiados pela legislação, será possível verificar quais os mais beneficiados e em que proporção, o que permitirá checar se é verdade 
que grupos profissionais são mais beneficiados pela atividade legislativa de determinados partidos políticos.

Quanto ao fato de a centro-esquerda legislar mais, podemos considerar três explicações: a) o eleitorado de uns e outros atribui diferentes graus de importância ao fato de o representante parlamentar efetivamente legislar, e assim apresentam mais proposições os parlamentares que percebem seus eleitores como mais atentos - no caso, a esquerda; b) os instrumentos para a maximização eleitoral variam muito conforme o partido, e os que dispõem de mais recursos que não a atividade legislativa se dispõem a utilizá-la menos, ou seja, a proposição legislativa é um último recurso para os que estão na oposição e, portanto, carecem de instrumentos concretos para transferir recursos. Como não ocupam cargos importantes no Executivo, que é o executor das políticas públicas e transferidor de recursos, sua única chance de mostrar compromisso é formulando propostas no Congresso, construindo assim o estereótipo desejado; c) ou, ainda, as transferências e regulações variam na natureza e no volume. Esse aspecto foge à nossa análise, mas deve ser mencionado: uma única proposta pode implicar a transferência de milhões, enquanto outras, apenas regulamentar uma profissão.

O Gráfico 1 mostra como funciona a lógica dos parlamentares. De acordo com o IAL, há mais propostas de benefícios difusos que de benefícios concentrados. Todos os representantes, independentemente do partido político, apresentaram propostas concentradoras. E a atividade legislativa é mais intensa nos grandes partidos de centro-esquerda e de esquerda - PT, PDT, PSDB e PMDB. Nesse processo, pôde-se identificar três padrões de escolha:

a) pequenos partidos à esquerda, $\mathrm{PDT}, \mathrm{PMDB}$ e PFL adotaram o geral: $\mathrm{RD}>\mathrm{RC}>\mathrm{TCR}>\mathrm{TDR}$;

b) $\mathrm{PT}, \mathrm{PSDB}$ e pequenos partidos à direita adotaram o padrão RD> RC> TDR>TCR;

c) PDS e PTB adotaram o padrão RD $>$ TCR $>$ RC $>$ TDR.

Note-se que não se verifica uma adesão ideológica, por blocos, aos tipos de proposta legislativa, a não ser no terceiro caso. No primeiro e no segundo padrões, partidos de esquerda, de centro e de direita podem partilhar da mesma ordem de escolhas (pequenos da esquerda, 


\section{Gráfico 1}

Partidos Políticos e Distribuição de Propostas Concentradoras e Difusas

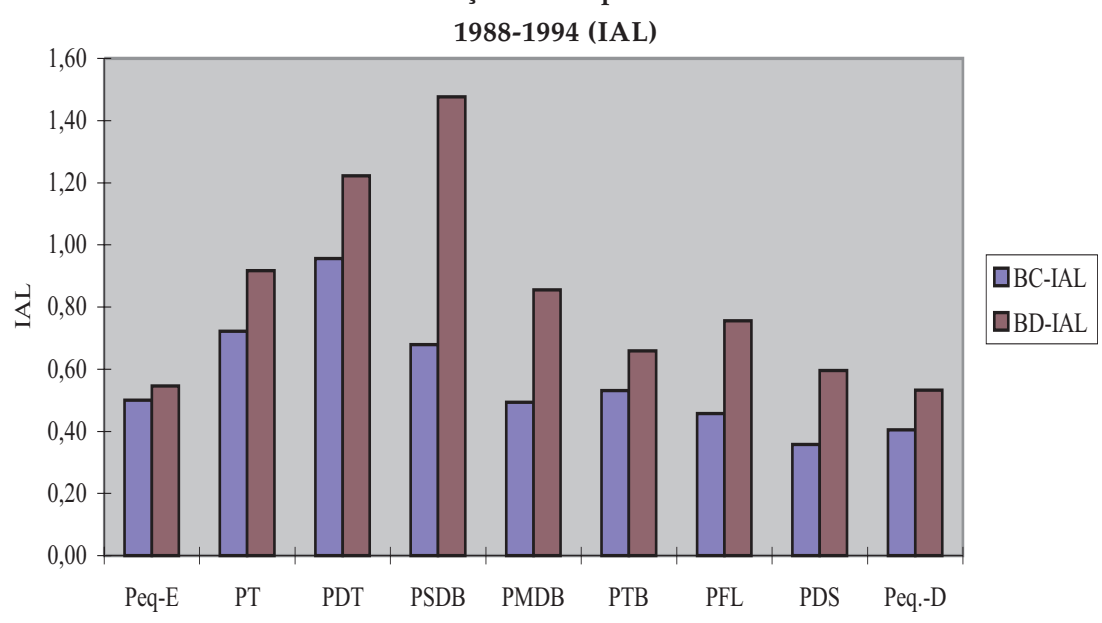

Obs.: BC-IAL: Benefícios Concentrados - Índice de Atividade Legislativa. BD-IAL: Benefícios Difusos - Índice de Atividade Legislativa.

PDT, PMDB e PFL no primeiro caso; no segundo, PT, PSDB e pequenos à direita). Verifica-se, então, que, se o Congresso apresenta um padrão coletivo de comportamento, ele não é a reprodução macrocósmica do comportamento das bancadas partidárias. Os partidos apresentam padrões distintos do padrão geral, mas o espectro ideológico é incapaz de explicar as alterações nas escolhas, visto que parlamentares afiliados a partidos ideologicamente diferentes, e até opostos, apresentam a mesma ordem de preferências.

\section{Como Funciona a Lógica Regional}

A segunda subhipótese testada foi confirmada. Os dados demonstram que parlamentares das cinco regiões apresentaram propostas concentradoras de benefícios, mantendo-se a prevalência das difusas sobre as concentradas, com exceção feita às propostas apresentadas pelas Comissões. Lembremos que o contraponto a essa hipótese é o argumento clássico de Furtado (1969) sobre parlamentares oriundos das regiões Nordeste e Norte. Por analogia, e seguindo uma concepção conservadora mas que domina o senso comum, poder-se-ia afirmar que os parlamentares oriundos de estados subdesenvolvidos seriam responsáveis por grande parte das propostas concentradoras e 
que, assim, inviabilizariam um projeto que mudasse o perfil social do país.

Entretanto, os dados demonstraram que os parlamentares das regiões economicamente mais desenvolvidas, Sul e Sudeste, aplicaram a lógica instrumental intensamente. Em relação ao número de propostas concentradoras apresentadas, levando-se em conta o IAL, tem-se, em primeiro lugar, o Centro-Oeste ${ }^{21}$; em segundo, o Sudeste; em terceiro, o Sul; em quarto, o Nordeste e por último a região Norte (Tabela 5). No que diz respeito às propostas concentradoras de benefícios, os representantes das regiões Norte e Nordeste legislam abaixo da média (0,56 proposta concentradora/parlamentar), 0,27 e 0,35, respectivamente. O IAL geral (somadas concentradas e difusas) foi de 1,40 proposta / parlamentar, enquanto a região Norte apresentou uma média de 0,55 proposta / parlamentar e a Nordeste 0,94 . Ou seja, os parlamentares do Norte e do Nordeste legislam menos e, em relação aos demais, apresentam um número inferior de propostas concentradoras de benefícios.

Tabela 5

Distribuição de Propostas Legislativas de Saúde e Educação, segundo a Região do Proponente e a Concentração de Benefícios 1988-1994

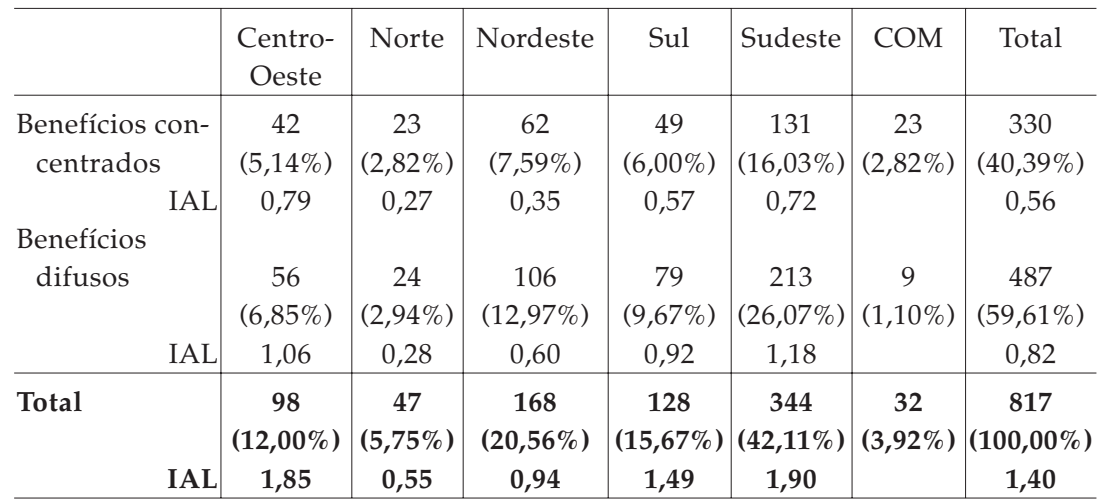

Fonte: Legis.

É preciso, entretanto, reconhecer dois elementos complicadores: a) o volume de transferências, que não é enxergado neste trabalho; b) nem sempre a concentração de benefícios está ligada ao distrito eleitoral respectivo, podendo estar vinculada a grupos de interesse. 
Quando desagregadas em RC, TCR, RD e TDR, verificamos os seguintes padrões de escolha:

a) Centro-Oeste, Norte e Sudeste reproduzem exatamente o padrão congressual $\mathrm{RD}>\mathrm{RC}>\mathrm{TDR}>\mathrm{TCR}$;

b) a região Sul apresenta o padrão RD > RC > TDR ou TCR;

c) a região Nordeste, $\mathrm{RD}>\mathrm{RC}>\mathrm{TDR}>\mathrm{TCR}$.

O desempenho das regiões demonstra novamente a predominância de regulação sobre transferência de recursos por parlamentares tanto de regiões desenvolvidas quanto de subdesenvolvidas. Curiosamente, transferir recursos para grupos específicos é a última opção dos parlamentares da região Nordeste, que carrega a fama de mais "paroquial". Se os parlamentares nordestinos e nortistas são os que mais aderem a práticas clientelísticas, não o são dentro do Congresso Nacional por meio da prerrogativa de legislar, pelo menos no que diz respeito às propostas legislativas do período compreendido entre 1988-1994, nas áreas de educação e saúde.

Após testar as três hipóteses, refutar a principal e confirmar as subsidiárias, considerou-se a distribuição temporal das propostas; quais grupos foram beneficiados e por que partidos; o perfil das propostas aprovadas e remetidas à sanção; os vetos presidenciais.

\section{A Distribuição Temporal das Propostas Legislativas}

Um dado importante que o Legis permite recuperar é a distribuição das propostas legislativas entre 1988 e 1994, para verificar se houve uma atividade legislativa maior nos períodos pré-eleitorais, aqui compreendidos como os anos em que efetivamente ocorreram as eleições: 1990 e 1994. Os dados indicam o contrário: os anos em que ocorrem as eleições são os de menor atividade legislativa, sendo os primeiros anos das legislaturas (198922 e 1991) os de maior intensidade, como demonstra o Gráfico 2.

Em 1989, 238 propostas foram apresentadas, contra $110 \mathrm{em} \mathrm{1990,} \mathrm{ano}$ de eleição. Em 1991, foram 177, contra 47 propostas apresentadas em 1994.

A constatação de que os parlamentares apresentam menos propostas em anos eleitorais pode ser explicada de quatro formas: a) para se co- 
Gráfico 2

Distribuição Temporal das Propostas Legislativas em Saúde e Educação

1988-1994

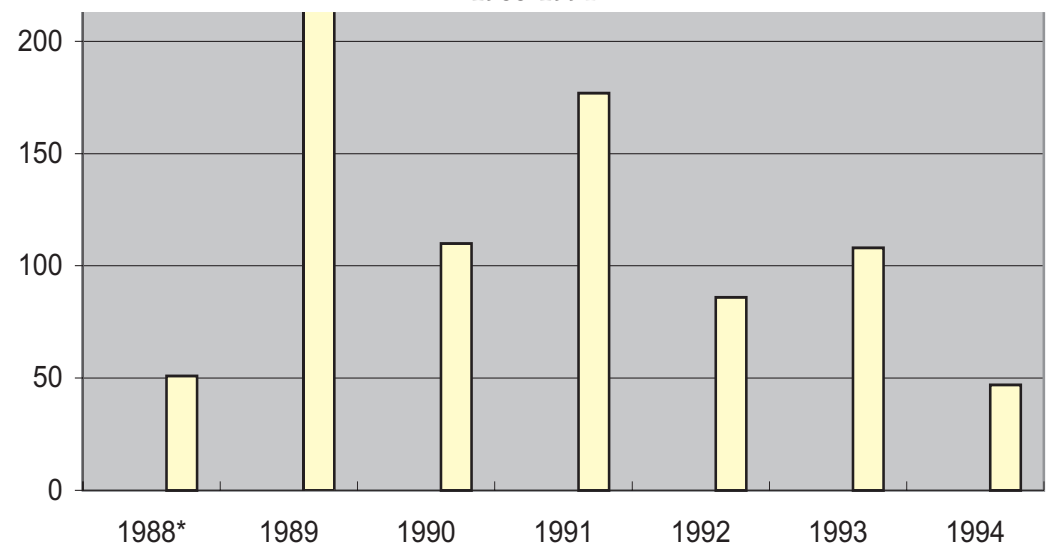

Fonte: Legis

* A partir de 5/10/1988.

lher os possíveis benefícios de propostas legislativas no período pré-eleitoral (ano da eleição), é preciso que as propostas sejam apresentadas bem antes das eleições, para que os parlamentares possam ter algum tempo para construir seu estereótipo; b) anos eleitorais demandam tempo e energia. A campanha exige que o parlamentar não esteja muito envolvido com a agenda do Legislativo. Para os debates, também é necessário que os representantes tenham uma imagem construída a partir de seu desempenho no Congresso; c) o Congresso brasileiro tem baixa taxa de reeleição. Isto significa que, para muitos representantes, o primeiro ano de mandato é uma oportunidade de mostrar aos eleitores suas posições e de cumprir promessas de campanha e compromissos. Os outros três anos, no caso dos deputados, ou sete, no dos senadores, podem ser utilizados para articulações; d) os dados até agora apresentados e as respectivas explicações delineadas apontam para uma possível segmentação da atividade parlamentar, em que, possivelmente, estão separadas em diferentes arenas não só a atividade legislativa propriamente dita (apresentação de projetos de lei e assemelhados) e a de fiscalização, mas especialmente a de transferência de recursos, que ocorreria na Comissão Mista de Orçamento. Esta Comissão pode significar um esvaziamento das funções distri-

\section{4}


butivistas da atividade legislativa propriamente dita. Isso implicaria uma visão menos homogênea do Legislativo, que na verdade estaria repartido não só ideologicamente mas operacionalmente. A idéia de um Congresso com diversas arenas e diferentes tipos de articulação e ganhos é também digna de ser revista em estudos posteriores.

Deve-se ressaltar que o fato de a atividade legislativa não se concentrar no ano eleitoral não quer dizer, exatamente, que ela não é utilizada para fins de reeleição, mas apenas que o processo de instrumentalização não é tão imediato quanto se supõe, e que ano eleitoral é ano de "corpo a corpo" com eleitor, não tempo de se começar a produzir propostas. Além disso, é importante chamar a atenção para o fato de que a existência de diferentes arenas pode implicar esforços empreendidos também de maneira diferenciada. Assim, havendo uma arena específica para a transferência de recursos, pode ser que em anos eleitorais ela seja a mais ativa, e não a de apresentação de propostas legislativas.

\section{Propostas Parlamentares e Possíveis Grupos Beneficiados}

Os grupos que receberiam mais benefícios, em ordem decrescente de preferência: a) grupos profissionais; b) grupos econômicos; c) estados; d) portadores de deficiência; e) mulheres; f) pacientes; g) outros; h) étnicos; i) religiosos.

Detectou-se um deslocamento da escolha do parlamentar de áreas geográficas para áreas temáticas, ou pelo menos uma combinação das duas coisas. Ainda que a localidade tenha importância, não se pode ignorar demandas de setores organizados, que se conformam como eleitores atentos e, durante períodos eleitorais e de campanha, podem tornar-se instigadores do público não atento e liderar opiniões acerca do desempenho e das preocupações dos parlamentares. Dentre eles, destacam-se os grupos profissionais das áreas de educação e saúde, que obtiveram $37,88 \%$ das propostas concentradoras de benefícios, e os grupos econômicos, que obtiveram $31,58 \%$ delas.

Os grupos econômicos foram classificados em três subgrupos: "patronal", "empregados", "outros", sendo este último correspondente a um grupo econômico obrigado à declaração anual de rendas - e, portanto, uma parcela da população que percebe acima de um teto - 
e que possui planos privados de saúde ou filhos menores em escolas privadas.

Tabela 6

Grupos Econômicos Beneficiados com Propostas Legislativas Concentradoras em Saúde e Educação

1988-1994

\begin{tabular}{l|c|c|c}
\hline & $\begin{array}{c}\text { Regulação } \\
\text { Concentrada }\end{array}$ & $\begin{array}{c}\text { Transferência } \\
\text { Concentrada de Recursos }\end{array}$ & Total \\
\hline Patronal & 15 & 16 & 31 \\
Empregados & 28 & 9 & 37 \\
Outros & 11 & 25 & 36 \\
\hline Total & $\mathbf{5 4}$ & $\mathbf{5 0}$ & $\mathbf{1 0 4}$ \\
\hline
\end{tabular}

Fonte: Legis.

O grupo "patronal" consegue um equilíbrio entre regulações e transferências de recursos, o grupo "empregados" consegue três vezes mais regulamentações que transferências e "outros" apresenta duas vezes mais transferências de recursos do que regulamentações. Isso ocorre, talvez, em decorrência da regulamentação ser mais importante para os trabalhadores do que a transferência de recursos, ou pelo fato de os parlamentares usarem a regulamentação mais intensamente para construir seu estereótipo.

A distribuição de propostas entre os grupos aponta igualmente uma conexão entre partidos e grupos econômicos específicos. O Gráfico 3 mostra a relação entre os partidos e a apresentação de propostas concentradoras de benefícios. Os partidos de esquerda e centro-esquerda apresentam mais propostas para "empregados" que os de direita e o PMDB (centro). De outro lado, os partidos de direita e centro-direita apresentam mais propostas para beneficiar o empresariado. O grupo econômico "outros" é mais beneficiado com propostas da centro-direita do que da esquerda.

Cumpre salientar a diferença entre "grupo profissional" e o subgrupo "empregados". O primeiro caso, diz respeito a profissões específicas - médicos, professores, radiologistas, empregados de biotérios, nutricionistas, funcionários em casas de saúde e em escolas. O segundo, "empregados", refere-se a todos aqueles protegidos pelas leis trabalhistas, formalmente inseridos no mercado de trabalho, mas sem mencionar qualificações específicas. Não são sinônimos. Entretanto,

\section{6}




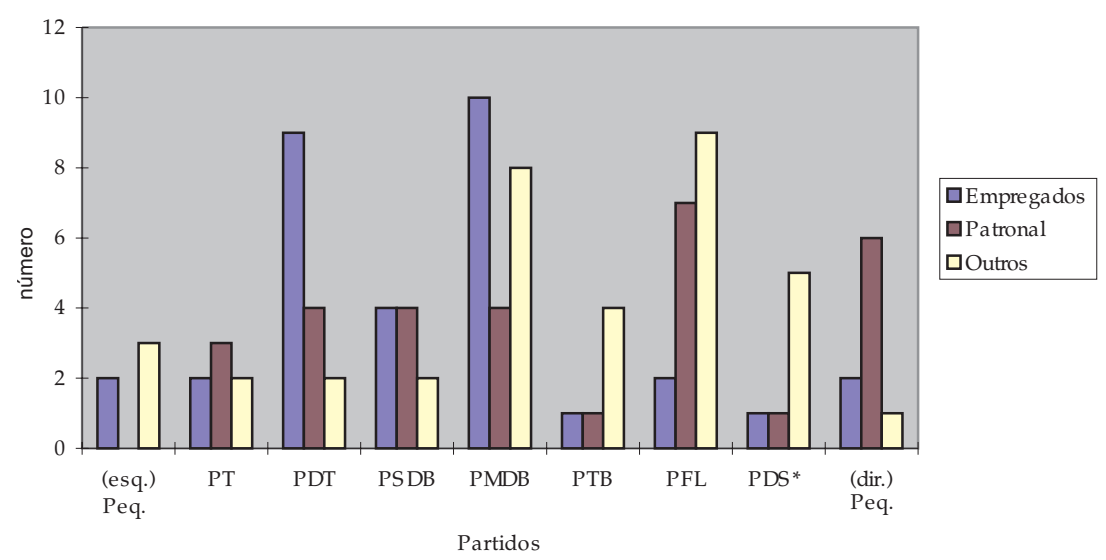

* O PDS fundiu-se com o PDC, transformando-se em PPR. Posteriormente, em 1995, o PPR fundiu-se com o PP para gerar o PPB.

se agregarmos o subgrupo de empregados e o grupo de profissionais, teremos uma atividade legislativa ainda mais concentrada nesses grupos, totalizando 161 propostas, cerca de $50 \%$ do total de propostas concentradoras.

O fato de o empresariado manter uma atividade menor que o grupo de empregados, ou de profissionais, não deve ser tomado como uma menor mobilização política no Legislativo. O que se pode dizer é que as duas áreas abordadas neste estudo podem ter um potencial de capitalização de recursos menor que outras áreas - como telecomunicações, energia, infra-estrutura -, ou um empresariado menos mobilizado. Pode ser ainda que os meios de capitalizar ganhos não ocorram no interior do processo legislativo, mas no âmbito do processo orçamentário propriamente dito, junto à burocracia. Sem dados mais completos, porém, nada aqui se pode afirmar sem cair em imprecisão.

O Gráfico 4 mostra que a esquerda e a centro-esquerda apresentam, agregadamente, mais propostas para os grupos profissionais, mas que a direita e a centro-direita não são indiferentes a eles. 
Gráfico 4

Partidos Políticos e Grupos Profissionais: Propostas de Saúde e Educação 1988-1994

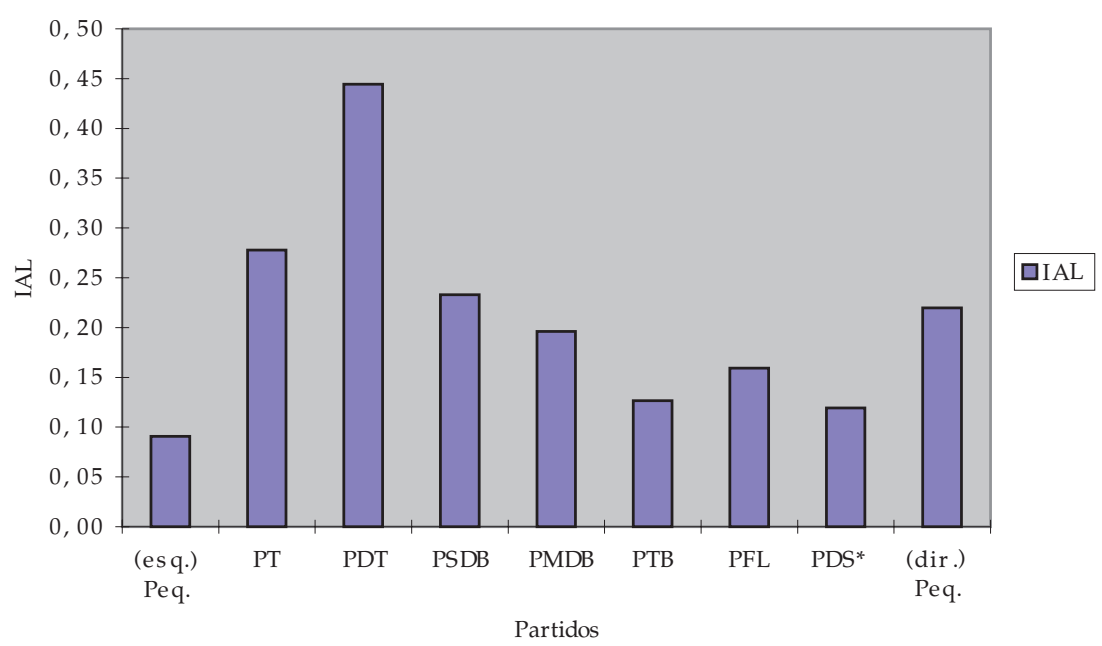

* O PDS fundiu-se com o PDC, transformando-se em PPR. Posteriormente, em 1995, o PPR fundiu-se com o PP para gerar o PPB.

\section{Propostas Apresentadas e Propostas Aprovadas}

As análises até agora mostradas levaram em conta todas as propostas apresentadas pelos parlamentares nas áreas de educação e saúde no período de 1988 a 1994, uma vez que a intenção era apreender a atuação do parlamentar. De agora em diante, a análise fica restringida às propostas aprovadas no Congresso.

O primeiro dado que salta aos olhos é o baixo aproveitamento das propostas legislativas, reforçando trabalhos recentes sobre a preponderância do Executivo sobre o Legislativo (Figueiredo e Limongi, 1994a; 1994b; 1995; 1999). Das 817 propostas apresentadas, apenas 53, ou $6,49 \%$ do total, foram aprovadas. Das aprovadas, 22,64\% (12 propostas) foram vetadas pelo presidente da República: 15,09\% totalmente e $7,55 \%$ parcialmente. Além disso, como desse total 5 eram propostas indicativas, que não eram, portanto, enviadas à sanção presidencial, porque eram apenas sugestões ao Executivo, somente 36 propostas efetivas foram aprovadas no Congresso e sancionadas pelo presidente sem vetos. Excluindo as propostas vetadas e as indicações, 
apresenta-se um percentual ainda menor de aproveitamento da atividade legislativa: $4,53 \%$.

As autorizações financeiras - AFs (autorizações de empréstimos junto a instituições de crédito externas, pedidas por estados), sempre de autoria das Comissões, são as que mais se transformam em norma. Esse tipo de autorização é competência privativa do Senado e uma de suas atribuições constitucionais. Isso significa que tal procedimento de autorização pode ser apenas uma formalidade (já que o empréstimo vem instruído por parecer do Banco Central e pelas formalidades do Ministério da Fazenda), não se configurando como disputa por recursos nem sendo em geral negado.

No confronto difusas $x$ concentradas, não se levando em conta as autorizações financeiras e as indicações, o padrão de difusas superando as concentradoras permanece: 24 difusas foram levadas à sanção contra 14 concentradoras. Se forem computadas as autorizações - como o foram para o teste da hipótese central e das demais - , as concentradoras somarão 25 e as difusas 24 , havendo então um equilíbrio entre ambas. Agregando-se ainda as indicações, haverá mais 4 difusas e 1 concentradora, revertendo o quadro: seriam 26 concentradoras e 28 difusas.

As regulações também superaram as transferências, como é o caso do conjunto das propostas legislativas do Congresso. Houve 43 regulações aprovadas (as autorizações financeiras computadas), contra apenas 6 transferências de recursos. Para esse caso, não são computadas as indicações, por não efetuarem qualquer regulação ou transferência de fato, apenas sugerindo que o Executivo o faça. O padrão geral das propostas aprovadas foi $\mathrm{RC}>\mathrm{RD}>\mathrm{TDR}>\mathrm{TCR}$.

Difere, portanto, do padrão anterior do Congresso quando eram analisadas todas as proposições ( $\mathrm{RD}>\mathrm{RC}>\mathrm{TCR}>\mathrm{TDR}$ ). No que diz respeito às proposições aprovadas, a última escolha é a TCR, e a preferida é a RC.

O Gráfico 5 mostra que os legisladores do PSDB e do PMDB foram os que mais conseguiram resultados positivos e que as Comissões tiveram um papel preponderante sobre os partidos. No que diz respeito ao PMDB, o resultado é previsível, já que esse era o partido do presidente e sua base no Congresso de 1992 a $1994^{23}$. Mas são os partidos de centro-esquerda e de esquerda que têm, em educação e saúde, o maior núme- 
Gráfico 5

Partidos Políticos e Proposições Aprovadas nas Áreas de Saúde e Educação 1988-1994

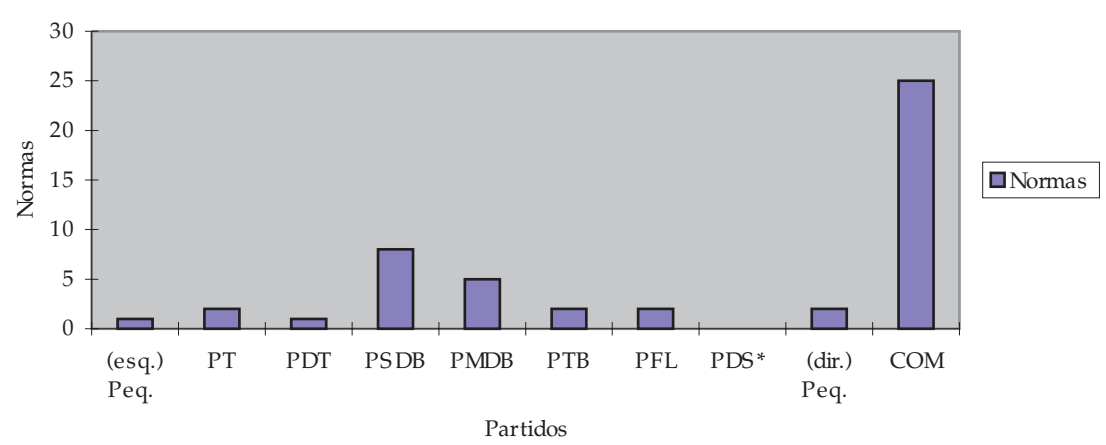

* O PDS fundiu-se com o PDC, transformando-se em PPR. Posteriormente, em 1995, o PPR fundiu-se com o PP para gerar o PPB.

ro absoluto de propostas legislativas aprovadas. Se considerado o IAL, proporcionalmente às suas bancadas, o partido mais bem-sucedido foi o PSDB. Os vetos, entretanto, recaíram também mais pesadamente sobre os partidos de esquerda e de centro-esquerda. Do total de 12 matérias vetadas, 2 foram da esquerda, 5 da centro-esquerda e 4 do centro, contra somente uma da direita.

As matérias aprovadas de iniciativa da esquerda, todas elas, sem exceção, dispersam benefícios, e mais sob a forma de regulamentação que sob a de transferência de recursos. Enquanto a esquerda apresenta mais propostas concentradoras que a direita, como foi verificado anteriormente, são suas propostas de cunho mais dispersivo as que conseguem apoio dos demais parlamentares e são aprovadas e enviadas à sanção. $\mathrm{O}$ fato de ter mais propostas aprovadas talvez se explique porque também a esquerda e a centro-esquerda são os mais ativos apresentadores de propostas.

Quanto à distribuição regional das propostas aprovadas, nota-se, novamente, a predominância das apresentadas pelas Comissões. Não só o número de propostas aprovadas foi muito maior que o das regiões, como nenhuma das aprovadas com origem em Comissões foi vetada parcial ou totalmente. De outro lado, tem-se a pouca expressividade das re- 
giões Norte, Centro-Oeste e Sul na aprovação de suas propostas - a região Sul teve sua única proposta aprovada, vetada totalmente.

Destaca-se a região Sudeste como a que se apresenta como a mais bem-sucedida - 14 propostas enviadas à sanção, sendo 2 vetadas totalmente e 3 parcialmente - , seguida pela região Nordeste. Embora esta região, no todo, apresente um número de propostas abaixo da média, ela tem, comparativamente às demais, um bom nível de aprovação (Tabela 7).

Tabela 7

Regiões Brasileiras e a Distribuição de Propostas Aprovadas pelo Congresso nas Áreas de Saúde e Educação

1988-1994

\begin{tabular}{l|c|c|c|c|c|c|c}
\hline & $\begin{array}{c}\text { Centro- } \\
\text { Oeste }\end{array}$ & Norte & Nordeste & Sul & Sudeste & Comissões & Total \\
\hline Aprovadas & 1 & 1 & 1 & 0 & 9 & 25 & 37 \\
& $(2,04 \%)$ & $(2,04 \%)$ & $(2,04 \%)$ & $(0,00 \%)$ & $(18,37 \%)$ & $(51,02 \%)$ & $(75,51 \%)$ \\
Veto total & 0 & 0 & 5 & 1 & 2 & 0 & 8 \\
Veto parcial & 0 & 0 & 1 & 0 & 3 & 0 & 4 \\
& $(0,00 \%)$ & $(0,00 \%)$ & $(10,20 \%)$ & $(2,04 \%)$ & $(4,08 \%)$ & $(0,00 \%)$ & $(16,33 \%)$ \\
\hline Total & $\mathbf{1}$ & $\mathbf{1}$ & $\mathbf{7}$ & $\mathbf{1}$ & $\mathbf{1 4}$ & $\mathbf{2 5}$ & $\mathbf{4 9}$ \\
& $(\mathbf{2 , 0 4 \% )}$ & $\mathbf{( 2 , 0 4 \% )}$ & $\mathbf{( 1 4 , 2 8 \% )}$ & $\mathbf{( 2 , 0 4 \% )}$ & $\mathbf{( 2 8 , 5 7 \% )}$ & $\mathbf{( 5 1 , 0 2 \% )}$ & $\mathbf{( 1 0 0 , 0 0 \% )}$ \\
\hline
\end{tabular}

Fonte: Legis.

Com exceção da região Norte - com uma proposta concentradora de benefícios aprovada - , as demais regiões foram bem-sucedidas em aprovar propostas de cunho difuso e as Comissões - loci privilegiados para aprovação de propostas - são as que mais apresentam propostas concentradoras. Isso reproduz, parcialmente, o padrão mais geral, em que se percebia uma maior atividade nas regiões Sul, Centro-Oeste e Sudeste e menor atividade nas regiões Norte e Nordeste. Confirmou-se a preponderância da região Sudeste e destacou-se a forma como se articula a Nordeste, que apresenta, proporcionalmente, menos propostas mas aprova mais.

A Tabela 8 mostra quem foram os beneficiados com as propostas aprovadas. Do total de 25 propostas que procuram concentrar benefícios, 11 foram autorizações financeiras para estados da federação e houve 1 
transferência de recursos para o Estado de Santa Catarina. Foram ao todo 12 propostas que beneficiariam estados. Diferentemente do total das propostas apresentadas nas Casas do Congresso, quando grupos de interesse prevaleciam como os possíveis beneficiários, as propostas aprovadas apontam como os principais beneficiários da atividade legislativa do Congresso as unidades da federação, não via proposição pessoal de parlamentares, mas via Comissões. Nenhuma proposta que lhes favorecia foi vetada parcial ou totalmente.

Tabela 8

Beneficiários das Propostas Aprovadas em Saúde e Educação

1988-1994

\begin{tabular}{|c|c|c|c|c|}
\hline & $\begin{array}{l}\text { Autorizações } \\
\text { Financeiras }^{24}\end{array}$ & $\begin{array}{l}\text { Regulação } \\
\text { Concentrada }\end{array}$ & $\begin{array}{c}\text { Transferência } \\
\text { Concentrada de } \\
\text { Recursos }\end{array}$ & Total \\
\hline Estados & $\begin{array}{c}11 \\
(44,00 \%)\end{array}$ & $\begin{array}{c}0 \\
(0,00 \%)\end{array}$ & $\begin{array}{c}1 \\
(4,00 \%)\end{array}$ & $\begin{array}{c}12 \\
(48,00 \%)\end{array}$ \\
\hline Econômicos & $\begin{array}{c}0 \\
(0,00 \%)\end{array}$ & $\begin{array}{c}6 \\
(24,00 \%)\end{array}$ & $\begin{array}{c}0 \\
(0,00 \%)\end{array}$ & $\begin{array}{c}6 \\
(24,00 \%)\end{array}$ \\
\hline Profissionais & $\begin{array}{c}0 \\
(0,00 \%)\end{array}$ & $\begin{array}{c}6 \\
(24,00 \%)\end{array}$ & $\begin{array}{c}1 \\
(4,00 \%)\end{array}$ & $\begin{array}{c}7 \\
(28,00 \%)\end{array}$ \\
\hline Total & $\begin{array}{c}11 \\
(44,00 \%)\end{array}$ & $\begin{array}{c}12 \\
(48,00 \%)\end{array}$ & $\begin{array}{c}2 \\
(8,00 \%)\end{array}$ & $\begin{array}{c}25 \\
(100,00 \%)\end{array}$ \\
\hline
\end{tabular}

Fonte: Legis.

O segundo grupo mais aquinhoado foi o de "profissionais": 6 regulações concentradas e 1 transferência concentrada de recursos, sendo que, dessas 6 regulações, somente 1 foi apresentada pelo PTB. As demais o foram por Comissões. Do total, somente 1 foi vetada totalmente.

O terceiro e último grupo beneficiado foi o denominado "econômico", com 6 regulamentações concentradas, apresentando a seguinte divisão: 4 regulamentações concentradas favorecendo "empregados" e 2 o grupo "patronal". Os ganhos dos trabalhadores superaram os patronais na ação legislativa. Mas não se deve esquecer que isso não significa que os últimos não se beneficiam do governo. Apenas que esses benefícios podem ser diretamente distribuídos pelo Executivo. Vale reafirmar a questão do volume de transferências ou o conteúdo das regulações, que podem ser significativos e esclarecedores.

592 
Se forem computados conjuntamente os grupos "profissionais" e "econômico-empregados", verificar-se-ão 11 propostas que beneficiam os trabalhadores. A divisão de benefícios ficaria, então: $48 \%$ para estados, $44 \%$ para trabalhadores (empregados + profissionais) e $8 \%$ para o grupo patronal. Há uma demonstração clara de uma forte presença da articulação dos estados no Congresso, além de uma grande atividade de grupos profissionais organizados.

Os demais grupos de interesse, ainda que tenham conseguido mobilizar-se para a apresentação de propostas, não conseguiram garantir que suas demandas chegassem ao fim do processo legislativo.

\section{CONSIDERAÇÕES FINAIS}

O objetivo deste trabalho foi compreender a lógica congressual no que diz respeito à forma e ao escopo das propostas de educação e saúde apresentadas entre 1988 e 1994. A hipótese central e as subsidiárias afirmavam que os legisladores escolheriam apresentar propostas concentradoras de benefícios em contraposição a benefícios difusos em toda a sociedade. Os dados indicaram que, em geral, os parlamentares preferiram apresentar propostas do último tipo, seja porque sua reeleição não estava sob ameaça, seja porque percebiam que as propostas tinham poucas chances de se tornarem políticas. A preferência por propostas difusoras poderia favorecer a construção de uma imagem "altruísta", eleitoralmente favorável, contrária à idéia do senso comum e de parte da literatura sobre o paroquialismo parlamentar.

Apesar dessa preferência, parlamentares de todo o espectro ideológico e de todas as regiões apresentaram propostas concentradoras. Outras questões incluídas na análise foram: a) a apresentação de mais projetos no primeiro ano de mandato dos parlamentares, como uma forma de amealhar apoio eleitoral nos anos de eleição; b) "quembeneficia-quem", mostrando uma identificação entre partidos e grupos eleitorais; c) um contraste entre proposições apresentadas/proposições aprovadas, demonstrando uma baixíssima porcentagem de propostas aprovadas $(6,49 \%)$; d) como o Executivo (nesse caso, o presidente) exercita sua capacidade de veto; e) a preponderância do trabalho das Comissões.

O Legislativo foi considerado especialmente pela sua prerrogativa constitucional de elaborar as diretrizes e normas a que estarão sujei- 
tos os cidadãos e sua capacidade de veto. Ainda que os trabalhos empíricos em curso nos últimos anos tenham demonstrado uma hipertrofia do Executivo e uma certa abdicação do Legislativo de sua prerrogativa de legislar, há ainda um longo percurso a se fazer antes de se afirmar que o Legislativo é um "braço morto" do corpo institucional. Na verdade, o que esses estudos estão a construir é a possibilidade de se estabelecer o que de fato realiza o Legislativo, e de que forma ele desempenha seu papel no caminho da democracia.

Nas relações Legislativo/Executivo, verifica-se um déficit de legitimidade ${ }^{25}$ e uma baixíssima capacidade de mobilização do próprio Legislativo no sentido de aprovar suas propostas. Cabe perguntar se tal atrofia das prerrogativas não seria proposital. Afinal, é o Legislativo quem faz as regras e tem capacidade de criar constrangimentos à excessiva incursão do Executivo na sua arena. Seria ingenuidade acreditar que o Legislativo é vítima de um processo opressivo movido pelo Poder Executivo, e não um colaborador voluntário das propostas deste último. Afinal, para o Executivo aprovar suas proposições é necessária a maioria, e muitas vezes qualificada. Se ele a tem, é porque há no Congresso, por parte de determinados partidos e grupos, disposição para apoiar essas medidas e não as originadas no próprio Legislativo.

A despeito dessa observação, é preciso incorporar ainda, nas análises, o componente histórico de nossas instituições. Não se sai impunemente de uma história de sucessivos golpes, patrimonialismo e corporativismo. A verdade é que o Congresso, recém-saído de um regime militar em que suas prerrogativas eram limitadíssimas - isso sem falar nas diversas vezes em que foi fechado e nas muitas cassações de mandato que sofreu por motivos políticos -, pode realmente enfrentar dificuldades para o estabelecimento de maior autonomia, até porque vários atores que desempenharam papéis centrais durante o regime militar continuam atuando politicamente. Assim, se a instituição não é autônoma, isso se deve também ao contexto específico nacional.

Os resultados da análise indicam que o particularismo no Congresso Nacional, portanto, depende de variáveis institucionais, ausentes no pré-1964, mas que emergem no período autoritário e permanecem no pós-1988, ou mesmo que surgem na nova ordem constitucional. O problema das prerrogativas do presidente da República, por exemplo, com o monopólio adquirido para legislar em questões tributárias

\section{4}


e orçamentárias é uma dessas variáveis: se no período 1946-1964 os congressistas podiam ativamente estabelecer isenção fiscal e propor créditos especiais e suplementares, no pós-1988 isso já não é possível, graças à concentração de mais esse poder nas mãos do chefe do Poder Executivo.

Por outro lado, vendo-se o Legislativo isoladamente e não em suas relações com o Executivo, colocou-se aqui, diversas vezes, que talvez a atividade parlamentar não seja tão homogênea como parece, muitas vezes, à opinião pública e mesmo a análises científicas. Tem-se, continuamente, ignorado certas idiossincrasias do processo legislativo brasileiro. Como se viu, a atividade legislativa é regulatória e difusora. Isso não quer dizer que o Legislativo não transfira ou concentre recursos, mas essas duas atividades podem estar centradas em outras arenas que não a propositiva.

O Congresso, a despeito das críticas, e embora certamente abarque o paroquialismo, atua predominantemente no sentido de difundir benefícios e não de concentrá-los, pelo menos no que diz respeito às áreas de educação e saúde no período 1988-1994 e à atividade estritamente legiferante. Não se pode deixar de atribuir tais resultados às regras e aos procedimentos que restringem a atividade particularista, bem como a limitações na estrutura burocrática do Legislativo e à segmentação da atividade parlamentar, em diversas arenas.

A visão segmentada do Congresso apresentaria dois aspectos: a segmentação vertical-hierárquica (Mesa Diretora, Comissões etc.) e a segmentação horizontal, em arenas assim organizadas: administrativa; legiferante (ou propositiva, onde se concentraria o tipo de atividade descrita neste trabalho); orçamentária (via Comissão Mista de Orçamento, especificamente de transferência de recursos, onde não cabe regulamentação ou fiscalização); fiscalizadora (via Comissões específicas); arena de Medidas Provisórias e Propostas de Emenda à Constituição de origem no Executivo. Assim, o parlamentar pode buscar sua maximização eleitoral de diferentes formas, com diversos instrumentos e nas diversas arenas.

Três foram os principais problemas encontrados na elaboração deste trabalho. O primeiro é que a análise se restringe às áreas de educação e saúde, e outras temáticas em que a opinião pública, lobbies e grupos de interesse atuem com mais intensidade podem apresentar diferen- 
ças nos resultados. Estudos comparativos com outros tipos de legislação-econômica, ambiental, de gênero etc. — podem esclarecer se há de fato essas variações ou vieses temáticos. O segundo problema é que a análise quantitativa diz respeito à distribuição numérica das proposições, mas não leva em conta seu conteúdo. Como aqui se lida com número de propostas, e não com seu conteúdo específico, não se pode medir exatamente o volume e a natureza dos benefícios transferidos. É verdade que uma proposta pode transferir, em termos volumétricos, mais do que cem propostas juntas, e que uma regulação profissional, por exemplo, pode resultar em uma transferência de recursos considerável. Mas esses aspectos devem ser analisados em outros estudos, qualitativos, capazes de apreender as minúcias das propostas legislativas em educação e saúde. O terceiro problema diz respeito ao período, relativamente curto, de coleta de dados. Quaisquer generalizações seriam precipitadas, dentro desses limites.

Em vista disso, haveria uma série de outros temas a serem tratados, desde uma análise mais ampla das diversas arenas a estudos sobre a estrutura hierárquica do Congresso, com estudos de agendas, composições partidárias e regionais, Comissões como loci decisórios, pesquisas sobre as Casas em separado - Câmara, Senado e Congresso Nacional - carreiras políticas e estudos de lideranças. Como um dos problemas deste trabalho é a especificidade dos temas, talvez uma análise do mesmo tipo com propostas da área de infra-estrutura ou da área econômica possibilite comparações frutíferas. Também o estudo de Legislativos comparados pode ser de grande importância para esclarecer pontos de tangência ou divergência do Legislativo brasileiro vis-à-vis outros Legislativos, latino-americanos ou não.

O ponto fundamental, entretanto, é crer que tais estudos podem colaborar para um profundo debate sobre os papéis institucionais e como melhor reformá-los para aproximá-los dos cidadãos. Representantes que não representam, ou que não despertam sentimentos de confiança no eleitorado são um peso e uma ameaça à democracia. Há um consenso quanto à necessidade de reformas institucionais - ainda que, quando nelas se fale, o discurso, praticamente, restrinja-se a questões partidárias e eleitorais. Somente conhecendo nossas instituições profundamente será possível criar um novo universo de regras e procedimentos mais legítimo e mais bem integrado. Sobretudo, é preciso crer que a ineficácia social não é um resultado necessário e inevitável: ao contrário, é o produto de escolhas políticas e de estruturas institucio-

\section{6}


O Congresso Brasileiro e a Distribuição de Benefícios Sociais...

nais que lhe permite subsistir. E ao mudar estruturas, para que elas condicionem escolhas promotoras do bem comum, é possível que desapareça nossa perversa herança social, surgindo daí uma sociedade, de fato, mais democrática.

(Recebido para publicação em maio de 2000)

(Versão final em abril de 2001)

\section{NOTAS}

1. O rendimento domiciliar per capita do Brasil decresce 13,8\% entre 1980 e 1988; a incidência total de pobreza (\% de domicílios com rendimento per capita menor do que um quarto do salário mínimo) eleva-se de 19,9\% para 26,2\% em 1988, e cresce mais na cidade que no campo; agrava-se a distribuição de renda no período (exceção feita a Curitiba), com os $5 \%$ mais ricos detendo quase sempre mais de $30 \%$ da renda e os $40 \%$ mais pobres, menos de $10 \%$. Alguns indicadores sociais evoluíram, ainda como resultado dos gastos realizados na década de 70, mas continuaram ostentando péssimos indicadores sociais, na comparação internacional, como mortalidade infantil e taxa de analfabetismo. Para mais dados, cf. Albuquerque (1993).

2. Na agenda dos governos, no período 1988-1994, predomina a questão da estabilidade econômica (Diniz, 1995), e há um certo consenso de que é preciso atacar primeiro os problemas fiscal e inflacionário para se gerar, depois, soluções que atendam à questão social (Pereira, 1992). Desse modo, os governos pós-88, apesar de terem se comprometido publicamente com a questão social, prometendo políticas que promovessem a redistribuição de renda e a eliminação da pobreza, colocaram como item no 1 da pauta a estabilidade econômica e a reforma do Estado. Essas medidas são vistas como precondição para um futuro ataque aos problemas sociais.

3. O postulado do Congresso como importante formulador de políticas, colocado aqui como pressuposto, é, na verdade, negado pelos trabalhos de Figueiredo e Limongi (1994a; 1994b; 1995; 1999) que colocam o Executivo como o efetivo legislador, seja via Medidas Provisórias, seja via propostas legislativas da base governista ou do próprio Executivo. Segundo os autores, cerca de 85\% das propostas que se transformam em norma jurídica são de autoria do Executivo. Apesar disso, não se pode negar o papel institucional-formal que cabe ao Legislativo, e o diferenciador fundamental entre os dois Poderes: o Legislativo é suscetível de avaliação direta por parte da população, podendo ser "trocado" quando não atende a expectativas. No Executivo, somente o presidente da República — que não é o formulador direto das políticas, papel este das tecnocracias - pode ser controlado pelo voto. 


\section{Leany Barreiro de S. Lemos}

4. Essa seção não traz um levantamento exaustivo da literatura, uma vez que ela é maior e mais complexa do que esse resumo. Sua intenção é apenas colocar o eixo da discussão, especialmente para não-iniciados.

5. A maximização da racionalidade não preclui a maximização de objetivos socialmente considerados altruístas. Apesar de as preferências serem definidas pelos indivíduos e, portanto, serem vistas como intrinsecamente egoísticas, de um ponto de vista moral, não carregam em si qualquer tipo de determinismo. Por outro lado, a teoria não se preocupa em valorar a utilidade — se a busca da reeleição se dá por justificativas ideológicas ou materiais.

6. O teorema do caos questiona a estabilidade das questões coletivas, apontando que não há relação entre preferência individual e resultado final. "Se não há um mediano em todas as direções, é possível construir uma agenda, ou uma seqüência de comparações de pares de alternativa, que leva a qualquer alternativa no espaço" (Hinich e Munger, 1997:160).

7. Aponta para a impossibilidade de uma decisão social única e estável que não seja ditatorial, portanto ilegítima, quando vige a regra da maioria (ver Arrow, 1963).

8. Já a partir dos anos 70 se iniciam teorizações formais de modelos distributivistas; portanto, anteriormente ao que se convencionou chamar neo-institucionalismo.

9. É esse pressuposto, de que o cálculo eleitoral permite uma margem de manobra das preferências, que pode, por exemplo, explicar por que não existem somente políticas particularistas e que sirvam a interesses organizados. Se, por um lado, é muito fácil explicar propostas que concentram benefícios geográficos ou de interesses porque permitem ao eleitor mapear as políticas até seu autor e, assim, premiá-lo com o voto - , por outro, as políticas que auferem benefícios difusos são mais complicadas de serem explicadas. Mas a verdade é que as eleições e as regras institucionais legislativas permitem a alternância das preferências dos parlamentares, e acabam impelindo a interesses gerais e particulares. Ver interessante discussão a esse respeito em Arnold (1991).

10. A teoria de que o Congresso é um obstáculo é apresentada por Furtado (1969). Segundo ele, por motivos ideológicos, a instituição vetava os ajustes macroeconômicos necessários ao crescimento industrial iniciado em 1955. Composto majoritariamente por representantes de estados subdesenvolvidos, vocalizava os interesses de agentes econômicos prejudicados por esse crescimento.

11. A concepção de que o Congresso procurava expandir os gastos públicos é apresentada por Ames (1986; 1987) e Campos (1966).

12. O público atento é aquele capaz de manifestar suas preferências e que tem conhecimento sobre as decisões que estão sendo tomadas. Note-se que não é sinônimo de público organizado, embora sejam relacionados. Manifestam-se desorganizadamente por meio de cartas, encontros, lobistas e mídia. Levam vantagem sobre o público desatento, cujas preferências precisam ser "adivinhadas" pelos legisladores.

13. Não só antecipam quais iniciativas podem vir a ser politicamente relevantes, como antecipam como seus votos em determinadas matérias não fundamentais para sua reeleição podem ser utilizados em épocas eleitorais, pelos adversários, para atingi-los negativamente.

14. O Anexo traz alguns exemplos de cada um dos tipos de decisão. 
O Congresso Brasileiro e a Distribuição de Benefícios Sociais...

15. Em 1995, a bancada de São Paulo aumentou de 60 para 70 deputados. Isso implicou aumento da bancada do Sudeste, passando a 179 (total a partir de $1995=513$ deputados), mas não apresenta implicações para este trabalho.

16. De fato, as burocracias e os instrumentos de aquisição de informações, especialmente na área econômica, estão funcionalmente ligados ao Executivo, permitindo-lhe elaborar o orçamento e apontar as transferências de recursos, enquanto ao Legislativo falta uma área técnica capaz de colher tais dados, ou mesmo agregá-los e analisá-los em profundidade. Por outro lado, há que se considerar a dificuldade de o Legislativo agir conforme critérios técnicos e não políticos, por ser intrinsecamente uma instituição pluralista e permeável aos múltiplos interesses da sociedade, diferentemente do Executivo, estruturalmente marcado pela burocracia e pela tecnicidade.

17. Fala-se aqui de ordenamento das escolhas, e não das preferências, pelo fato de estas poderem ser muito diferentes daquelas. Na verdade, a escolha está contingenciada pelas restrições conjunturais ou estruturais a que esteja exposto o parlamentar (instituições, competição entre parlamentares, pressão da opinião pública etc.).

18. Esta análise não mede o volume de recursos transferido por cada uma das propostas ou o número de pessoas que seriam beneficiadas. Trata apenas do número de propostas e não de seu peso.

19. A satisfação de interesses particulares, dependendo do grupo atingido e da forma como ela se dá, pode ser fundamental para uma redistribuição de renda e de direitos mais justa, promovendo não um aprofundamento de desigualdades, mas a correção de diferenças que se traduzem em exclusões.

20. Note-se que a aspiração do eleitorado não necessariamente precisa estar atrelada à satisfação de interesses individualísticos, mas a valores. É possível que um eleitorado perceba a satisfação de um grupo desprivilegiado pela sociedade - mulheres, negros, índios, deficientes - como um bem público e, a partir da avaliação de como o parlamentar se comporta em relação a essas minorias, votar ou não no candidato.

21. O fato de a região Centro-Oeste ter tão alto índice de atividade concentradora se deve ao fato de o Distrito Federal estar localizado nessa região e ter havido no Senado Federal, até a instalação da Câmara Legislativa Distrital, em 1990, uma Comissão Permanente responsável, dentre outras coisas, pelas proposições legislativas pertinentes ao Distrito Federal, pelo seu orçamento e pela fiscalização das contas do governo do DF, uma vez que essa unidade da federação não possuía representação legislativa própria. Com a posse dos deputados distritais em 15 de março de 1990, prevista na Constituição de 1988, estabelece-se a representação legislativa própria do Distrito Federal e extingue-se a Comissão do DF no Senado Federal (para as atribuições específicas da Comissão Permanente do DF, cf. Regimento Interno do Senado Federal, 1986, título VI, cap. VI, art. 105; título XIV, cap. VI, art. 413). Mesmo após criada a Câmara Distrital, com a obrigação de a União prover repasses orçamentários para a manutenção dos serviços de educação, saúde e segurança pública no Distrito Federal, essa unidade da federação surge como um canalizador de demandas financeiras para a União, com a diferença de que enfrenta uma disputa menos acirrada com as outras unidades, uma vez que os repasses the são constitucionalmente garantidos (consultar o art. 16ำ do Ato das Disposições 


\section{Leany Barreiro de S. Lemos}

Transitórias da Constituição Federal de 1988; Regimento Interno do Senado Federal, 1988).

22. Deve-se ressaltar que o ano de 1989 atende a uma particularidade: apesar de as eleições terem acontecido em 1986, os anos de 1987 e 1988 foram anos de Assembléia Constituinte, em que os parlamentares concentraram esforços na elaboração da Carta. O ano de 1989 foi, portanto, o primeiro ano de atividade legislativa regular após promulgada a Constituição, sob novas regras. Com isso, esse ano é considerado, para fins de análise, como ano inicial de legislatura.

23. Recorde-se que as eleições presidenciais de 1989 elegeram o presidente Fernando Collor de Mello, do PRN, mas em 1992, tendo sofrido impeachment sob suspeitas de corrupção, toma assento no cargo o vice-presidente Itamar Franco, do PMDB.

24. Para testagem da hipótese central, computada como TCR.

25. Lembremos que o Legislativo é o único dos Poderes totalmente constituído a partir da representação popular, enquanto no Judiciário a representação é nula e, no Executivo, restringe-se ao presidente da República. Afora ele, os demais elaboradores e implementadores de políticas estão fora do alcance dos cidadãos, insulados e non-accountable.

\section{REFERÊNCIAS BIBLIOGRÁFICAS}

ALBUQUERQUE, Roberto C. de (org.). (1993), O Brasil Social: Realidades, Desafios, Opções. Rio de Janeiro, IPEA.

AMES, Barry. (1986), “O Congresso e a Política Orçamentária no Brasil durante o Período Pluripartidário". Dados, vol. 29, no⒉

_. (1987), Political Survival: Politicians and Public Policy in Latin America. Berkeley, University of California Press.

ARNOLD,Douglas R. (1991), The Logical of Congressional Action. New Haven, Yale University Press.

ARROW, Kenneth J. (1963), Social Choice and Individual Values. New York, John Wiley and Sons.

BRASIL, CONGRESSO, SENADO FEDERAL. (1986), Regimento Interno. Brasília, Centro Gráfico do Senado Federal.

_. (1998), Constituição de 1988 (6ª ed.). Brasília, Centro Gráfico do Senado Federal.

CAMPOS, Roberto. (1966), “O Poder Legislativo e o Desenvolvimento”, in C. Mendes (ed.), O Legislativo e a Tecnocracia. Rio de Janeiro, Imago Editora/Conjunto Universitário Candido Mendes.

DINIZ, Eli. (1995), “Governabilidade, Democracia e Reforma do Estado: Os Desafios da Construção de uma Nova Ordem no Brasil dos Anos 90". Dados, vol. 38, no 3 .

\section{0}




\section{O Congresso Brasileiro e a Distribuição de Benefícios Sociais..}

ELSTER, Jon. (1989), “Marxismo, Funcionalismo e Teoria dos Jogos: Argumentos em favor do Individualismo Metodológico". Lua Nova, no 17.

FIGUEIREDO, Argelina Cheibub e LIMONGI, Fernando. (1994a), “Mudança Constitucional, Desempenho do Legislativo e Consolidação Institucional". Revista Brasileira de Ciências Sociais, ano 10, no⒉

_. (1994b), “O Processo Legislativo e a Produção Legal no Congresso Pós-Constituinte". Novos Estudos Cebrap, no 38.

__. (1995), "Partidos Políticos na Câmara dos Deputados: 1989-1994". Dados, vol. 38, no 3.

_. (1999), Executivo e Legislativo na Nova Ordem Constitucional. Rio de Janeiro, Fundação Getulio Vargas Editora/FAPESP.

FURTADO, Celso. (1969), "Political Obstacles to Economic Growth", in C. Velliz (ed.), Obstacles to Change in Latin America. London, Oxford University Press.

GREEN, Donald P. e SHAPIRO, Ian. (1994), Pathologies of Rational Choice Theory: A Critique of Applications in Political Science. New Haven, Yale University Press.

HINICH, Melvin e MUNGER, Michael. (1997), Analytical Politics. Cambridge, Cambridge University Press.

KHREBIEL, Keith. (1991), Information and Legislative Organization. Ann Arbor, The University of Michigan Press.

KNIGHT, J. (1992), Institutions and Social Conflict. Cambridge, Cambridge University Press.

LIMONGI, Fernando P. (1994), “O Novo Institucionalismo e os Estudos Legislativos: A Literatura Norte-Americana Recente". Revista Brasileira de Informação Bibliográfica em Ciências Sociais - BIB, nํㅜ 37 .

MCKENZIE, Richard e TULLOCK, Gordon. (1985), Modern Political Economy: An Introduction to Economics. New York, McGraw-Hill International Book Company.

PEREIRA, Luiz Carlos Bresser. (1992), “A Crise da América Latina: Consenso de Washington ou Crise Fiscal?", in A Crise do Estado: Ensaios sobre a Economia Brasileira. São Paulo, Nobel.

PRZEWORSKI, Adam. (1988), "Marxismo e Escolha Racional". Revista Brasileira de Ciências Sociais, vol. 3, no 6 .

RIKER, J. (1990), "Political Science and Rational Choice", in E. Alt e K. A. Shepsle (orgs.), Perspectives on Positive Political Economy. Cambridge, Cambridge University Press.

SANTOS, Fabiano Guilherme M. (1995a), “Microfundamentos do Clientelismo Político no Brasil: 1959-1963". Dados, vol. 38, nº 3 .

_. (1995b), “Clientelismo como Escolha Racional”. Ciências Sociais Hoje, 1995. São Paulo, Anpocs/Hucitec, pp. 105-137.

WEINGAST, Barry e MARSHALL, William. (1988), "The Industrial Organization of Congress". Journal of Political Economy, no 96. 


\section{ABSTRACT \\ The Brazilian Congress and the Distribution of Social Benefits during the Period 1988-1994: A Distributive Analysis}

This study deals with the behavior of members of the Brazilian Congress in the areas of education and health in legislative activity from 1988 to 1994 . A database was produced with all 817 bills presented during the period in order to test hypotheses. Three hypotheses were tested for distributist behavior: whether members of Congress tended to "concentrate" resources as opposed to "spreading" them, a hypothesis which was rejected; whether there was a connection between "resource-concentrating" legislative bills and ideological spectrum or region, both confirmed. The study also highlighted that most bills tended to be submitted in the early years of the member's term; that the main beneficiaries were economic and professional groups and States of the country; that $6.49 \%$ of the bills submitted to Congress were approved; and that the bills, as approved, maintained practically all of their characteristics as originally submitted.

Key words: Brazilian Legislature; distributive behavior; social policies; national congress.

\section{RÉSUMÉ}

Le Congrès Brésilien et la Distribution des Bénéfices Sociaux dans le Période 1988-1994: Une Analyse Distributiviste

Ce travail traite le comportement des parlementaires dans les aires de l'éducation et de la santé, dans le contexte de leur activité légiférante, de 1988 à 1994. Une banque de données, avec la totalité des normes présentées dans cette période (817), a été élaboré, dans le but de tester des hypothèses concernant le comportement distributiviste des parlementaires. Il s'agissait de savoir: si les parlementaires étaient plus "concentrateurs » que «distributeurs » de ressources - hypothèse réfutée; s'il y avait un lien entre les propositions législatives « concentratrices » et un spectre idéologique ou une région du Brésil — hypothèses prouvées. On a pu également constaté que la plupart des propositions ont été présentées au Congrès dans les premières années du mandat; que les groupes ayant bénéficiéle plus de ces propositions ont été les groupes économiques, professionnels et les États de la fédération; que le pourcentage des propositions présentées ayant été approuvé par le Congrès a été de 6,49\%; enfin, que les propositions approuvées gardaient quasiment toutes les caractéristiques de celles présentées.

Mots-clés: Législatif brésilien; comportement distributionnel; politiques sociales; Congrès national 
O Congresso Brasileiro e a Distribuição de Benefícios Sociais...

ANEXO

\section{Exemplos de Propostas Legislativas}

\section{Transferência Concentrada de Recursos - TCR}

— Projeto de Lei da Câmara dos Deputados no 3.344, de 17/8/1989Dispõe sobre a concessão de adicional de insalubridade aos trabalhadores que atuem no combate à raiva dos animais herbívoros;

— Projeto de Lei da Câmara dos Deputados nº 4.681, de 29/6/1994 Dispõe sobre as condições e funcionamento de serviços de saúde para as populações indígenas (com criação de subsistema do SUS);

— Projeto de Lei da Câmara dos Deputados no 1.548, de 20/9/1991 — Estabelece o décimo quarto salário-livro para os professores, com a finalidade que menciona.

\section{Regulação Concentrada - RC}

— Projeto de Lei da Câmara dos Deputados no 1.542, de 16/9/1991 — Dispõe sobre a obrigatoriedade do exame de prevenção do câncer ginecológico para as funcionárias públicas federais;

— Projeto de Lei do Senado no 42, de 2/4/1991 — Estabelece normas de proteção à saúde dos trabalhadores de biotérios e dá outras providências;

— Projeto de Lei da Câmara dos Deputados no 3.290, de 14/8/1989 _ Dispõe sobre o exercício da profissão de treinador desportivo e dá outras providências.

\section{Transferência Difusa de Recursos - TDR}

— Projeto de Lei da Câmara dos Deputados no 01687, de 31/10/1991 - Dispõe sobre a seleção e construção de depósitos definitivos de rejeitos radioativos de responsabilidade da União, cria sistemas de radioproteção e dá outras providências;

— Projeto de Lei da Câmara dos Deputados no 961, de 24/5/1991 — Dispõe sobre o salário-educação;

\section{Regulação Difusa - RD}

— Projeto de Lei do Senado Federal no 354, de 27/10/1989 - Dispõe sobre o acondicionamento, a coleta, o tratamento, o transporte e a destinação final dos resíduos de serviços de saúde;

— Projeto de Lei da Câmara dos Deputados no 1.511, de 17/9/1991 — Estabelece novas faixas etárias para a prestação de exames supletivos de primeiro e segundo graus. 
Leany Barreiro de S. Lemos

\section{GLOSSÁRIO}

COM - Comissões

PCB - Partido Comunista Brasileiro

PCdoB - Partido Comunista do Brasil

PDC — Partido Democrata Cristão

PDS - Partido Democrático Social

PDT - Partido Democrático Trabalhista

PFL — Partido da Frente Liberal

PJ — Partido da Juventude

PL - Partido Liberal

PMDB — Partido do Movimento Democrático Brasileiro

PMN — Partido da Mobilização Nacional

PP — Partido Progressista

PPB - Partido Progressista Brasileiro

PPR — Partido Progressista Reformador

PPS — Partido Popular Socialista

PRN — Partido da Reconstrução Nacional

PRS - Partido das Reformas Sociais

PRONA - Partido da Reedificação da Ordem Nacional

PSB — Partido Socialista Brasileiro

PSC — Partido Social Cristão

PSD - Partido Social Democrático

PSDB - Partido da Social Democracia Brasileira

PST — Partido Social Trabalhista

PSTU - Partido Socialista dos Trabalhadores Unificado

PT — Partido dos Trabalhadores

PTB - Partido Trabalhista Brasileiro

PTdoB - Partido Trabalhista do Brasil

PTR - Partido Trabalhista Renovador

PV - Partido Verde

\section{4}


O Congresso Brasileiro e a Distribuição de Benefícios Sociais...

\author{
ABSTRACT \\ The Brazilian Congress and the Distribution of Social Benefits during \\ the Period 1988-1994: A Distributist Analysis
}

This study is about the behavior of Brazilian Congress members, concerning education and health bills from 1988 to 1994. A 817-bills database was built in order to test three hypotheses: whether members of Congress tended to "concentrate" resources as opposed to "spreading" them, a rejected hypothesis; whether there was a connection between "resource-concentrating" action and ideological spectrum; region, both confirmed. The paper also highlights that most bills tended to be submitted in the early years of member's term; who would be the main beneficiaries of the bills, presenting a link political parties-benefited groups; and the low approval capacity of Brazilian Legislative, while a high veto activity from the Executive body.

Key words: Brazilian Legislature; distributist behavior; legislative action; social policies; Executive-Legislative relations

\title{
RÉSUMÉ
}

Le Congrès Brésilien et la Distribution des Bénéfices Sociaux dans le Période 1988-1994: Une Analyse Distributiviste

Ce travail traite le comportement des parlementaires dans les aires de l'éducation et de la santé, dans le contexte de leur activité légiférante, de 1988 à 1994. Une banque de données, avec la totalité des normes présentées dans cette période (817), a été élaboré, dans le but de tester des hypothèses concernant le comportement distributiviste des parlementaires. Il s'agissait de savoir: si les parlementaires étaient plus "concentrateurs" que "distributeurs" de ressources - hypothèse réfutée; s'il y avait un lien entre les propositions législatives "concentratrices" et un spectre idéologique ou une région du Brésil - hypothèses prouvées. On a pu également constaté que la plupart des propositions ont été présentées au Congrès dans les premières années du mandat; que les groupes ayant bénéficié le plus de ces propositions ont été les groupes économiques, professionnels et les États de la fédération; que le pourcentage des propositions présentées ayant été approuvé par le Congrès a été de 6,49\%; enfin, que les propositions approuvées gardaient quasiment toutes les caractéristiques de celles présentées.

Mots-clés: Législature brésilienne; comportement distributionnel; action législatif; politiques sociales; relations Exécutif-Législatif 